\title{
1 Neurotoxicity induced by Microcystins and Cylindrospermopsin: A review
}

2 Hinojosa MG, Gutiérrez-Praena D, Prieto AI*, Guzmán-Guillén R, Jos A, Cameán AM

3 Area of Toxicology, Faculty of Pharmacy, Universidad de Sevilla, C/Profesor García

4 González 2, 41012 Seville, Spain.

5

6

7

8

9

10

11

12

13

14

$15 *$ Corresponding author: Ana Isabel Prieto Ortega (anaprieto@us.es). Area of

16 Toxicology, Faculty of Pharmacy, Universidad de Sevilla, C/Profesor García González

17 2, 41012 Seville, Spain.

18 


\section{Abstract}

20

21

22

Microcystins (MCs) and cylindrospermopsin (CYN) are among the most frequent toxins produced by cyanobacteria. These toxic secondary metabolites are classified as hepatotoxins and cytotoxin, respectively. Furthermore, both may present the ability to induce damage to the nervous system. In this sense, there are many studies manifesting the potential of MCs to cause neurotoxicity both in vitro and in vivo, due to their probable capacity to cross the blood-brain-barrier through organic anion transporting polypeptides. Moreover, the presence of MCs has been detected in brain of several experimental models. Among the neurological effects, histopathological brain changes, deregulation of biochemical parameters in brain (production of oxidative stress and inhibition of protein phosphatases) and behavioral alterations have been described. It is noteworthy that minority variants such as MC-LF and -LW have demonstrated to exert higher neurotoxic effects compared to the most studied congener, MC-LR. By contrast, the available studies concerning CYN-neurotoxic effects are very scarce, mostly showing inflammation and apoptosis in neural murine cell lines, oxidative stress, and alteration of the acetylcholinesterase activity in vivo. However, more studies are required in order to clarify the neurotoxic potential of both toxins, as well as their possible contribution to neurodegenerative diseases.

Keywords: cyanotoxins, MCs, CYN, nervous system, ecotoxicology, environmental risk. 


\section{Introduction}

Cyanobacteria are a group of Gram-negative prokaryotes capable of growing under almost every environmental condition (Chorus and Bartram, 1999). Due to climate change and anthropogenic activities, their presence is increasing (Davis and Gobler, 2016). As a consequence, there is an enhancement of the production of toxic secondary metabolites of great importance for the ecotoxicology known as cyanotoxins (Duy et al., 2000). These toxins are classified as hepatotoxins (e.g. microcystins, nodularins), cytotoxins (e.g. cylindrospermopsin), neurotoxins (e.g. anatoxin-a, homoanatoxin, saxitoxins), dermatotoxins (e.g. lungbyatoxin) or irritant toxins (e.g. lipopolysaccharides) (Testai et al., 2016). There are different exposure routes for cyanotoxins, being the most important the oral route. In fact, many aquatic organisms are able to live in presence of cyanotoxins, and some of them have proved to bioaccumulate these secondary metabolites, acting as a reservoir for animals higher up the trophic chain, and also for humans (Berry and Lind, 2010; Gutiérrez-Praena et al., 2013). However, dermal, inhaling or even parenteral exposures are also possible (Buratti et al., 2017). Thus, the variety of targets and exposure routes together with the rise of cyanobacterial proliferations make of cyanotoxins a serious concern for animal livestock, human activities and public health (Testai et al., 2016).

In the last decades, the toxic effects of cyanotoxins on the nervous system have been widely studied, not only those caused by the so-called neurotoxins with welldefined mechanisms of action in this system such as anatoxins (ATX) and saxitoxins (STX), but also, by other cyanotoxins with different target organs (Florczyk et al., 2014). Neurotoxicity could be described as 'any adverse effect on the central or peripheral nervous system caused by chemical, biological or physical agents' (Costa et 
al., 2008). The keys to the brief communication within the nervous system are the generation of a potential of action as a quick response of dendrites to the neurotransmitters released from contiguous neurons, and its fast travelling for the neuronal axon for its release afterwards (Kem, 2000).

In this sense, among all the cyanotoxins, microcystins (MCs) and cylindrospermopsin (CYN) have proven to exert damage in the nervous system as well, in spite of not being considered as neurotoxins per sé. These are very common cyanotoxins (Table 1) able to put health at risk due to their ubiquity (Gutiérrez-Praena et al., 2013), as previously demonstrated in different human poisoning cases. The most serious episode associated with human exposure to MCs occurred when 126 people were intoxicated at a haemodialysis clinic in Caruaru (Brazil), causing the death of almost half of them. All patients presented malaise, weakness, dizziness, vertigo, tinnitus, mild deafness and, in severe cases, visual disturbance and blindness, grand mal convulsions, and gastrointestinal and hepatic symptoms (Pouria et al., 1998; Carmichael et al., 2001). Most of these symptoms have a neuronal origin, standing out the possible MCs-crossing the blood-brain barrier (BBB) as several authors have reported (Feurstein et al., 2009; 2010; 2011; Zhao et al., 2015a), causing their toxic effects.

In the case of CYN, the most important outbreak occurred in Palm Island (Australia) in 1979, when 146 people were hospitalized with symptoms of malaise, vomits, anorexia, and hepatomegaly after drinking from a water supply that contained a CYN-producing Cylindrospermopsin raciborskii strain (Bourke et al., 1983; Griffiths and Saker, 2003). However, it is important to mention that CYN was also present in the Caruaru outbreak, possibly contributing to the neurological affectation reported (Bláha et al., 2009) although it is hard to differentiate the effects caused for each toxin in the 
90

symptoms observed, as both toxins are often present together in nature (Gkelis and Zaoutsos, 2014; Trainer and Hardy, 2015; Loftin et al., 2016; Buratti et al., 2017). Due to the low molecular weight of CYN, it might be able to cross the BBB. In fact, CYN was detected in brains of two fish species (Guzmán-Guillén et al., 2015; da Silva et al., 2018). Thus, although not being considered as neurotoxins, both cyanotoxins have demonstrated its neurotoxic potential in different in vitro and in vivo experimental models, increasing the interest of the scientific community in this matter. Taking into account all these facts, the aim of the present work was to gather the existent knowledge about the potential to exert neurotoxic effects of both toxins from 1998 to 2018 .

\section{Microcystins}

Microcystins (MCs) are cyclic heptapeptides molecules containing a hydrophobic $\mathrm{C}_{20}$ D-amino acid commonly known as ADDA (3-amino-9-methoxy-2,6,8trimethyl-10-phenyldeca-4,6-dienoic acid), crucial for the toxicity of these cyanotoxins due to their interaction with protein phosphatases (Song et al., 2006) (Fig. A). More than 246 isoforms of MCs have been detected (Spoof and Catherine, 2017), mainly differing in the L-amino acids at positions 2 and 4, causing differences in toxicokinetic and toxicodynamic properties (Rinehart et al., 1994). These compounds are the most widespread cyanobacterial toxins detected in freshwaters (Spoof and Catherine, 2017), being many the cyanobacteria genera capable of synthesize them: Microcystis, Plankthotrix, Anabaena, Nostoc, Aphanizomenon, Anabaenopsis, Rivularia and Fisherella, among others (Sivonen and Jones, 1999; Rao et al., 2002; Carey et al., 2007; Bittencourt-Oliveira et al., 2014; Cirés et al., 2014).

The most known mechanism of action of MCs is the protein serine/threonine phosphatases inhibition, able to cause phosphoprotein-deregulation, which leads to 
tumor promotion and apoptosis (MacKintosh et al., 1990; Vichi et al., 2016).

115 Furthermore, the potential of MCs to increase reactive oxygen species (ROS) and to reduce glutathione (GSH) levels, causing oxidative stress and, therefore, apoptosis, has already been demonstrated (Puerto et al., 2011; Wang et al., 2013; Li et al., 2015; Liu et al., 2016; Qian et al., 2018). Although being considered as hepatotoxins, MCs can damage other organs such as intestines, heart or kidneys (Moreno et al., 2003; Atencio et al., 2008; Qiu et al., 2009; Li et al., 2011a; Zeng et al., 2014). In this sense, it has been demonstrated that MCs require organic anion transporting polypeptides (OATPs for humans/ Oatps for rodents) in order to cross cell membranes (Chen and Xie, 2016). The OATP1B1 and OATP1B3 are common in liver cells, while OATP1A2 is thought to be the responsible for the transport of MC-LR, across the BBB and the kidneys, for example (Fischer et al., 2005; Feurstein et al., 2009). This means that significant amounts of MCs could reach the brain across the BBB and induce brain pathology, depending on the type and expression of OATPs/Oatps at the BBB, the bloodneurotoxic effects in several experimental models, although other more toxic congeners such as MC-LW and MC-LF have also been studied (Feurstein et al., 2009; 2010; 2011; Rozman et al., 2017). This can be due to the hydrophobicity of MC-LF and MC-LW. Structure variations and differences in molecular properties such as 
139 (2016) and Mello et al. (2018) have reviewed the main mechanisms of neurotoxicity of 140 MCs at different levels. Firstly, neurotransmission, by causing effects on GABAergic neurons. Secondly, neurochannels, by affecting the ionic concentrations in and outside the cells. Linked to this, signal transduction, as a consequence of the deregulation of $\mathrm{Ca}^{2+}$, which, by activating calcineurin leads to apoptosis. Moreover, the production of oxidative stress, by deregulating several antioxidant enzymes such as catalase or superoxide dismutase (SOD). And finally, cytoskeleton disruption, by alteration of structural brain proteins such as Tau. However, important contributions have been made lately, confirming these mechanisms using mostly in vivo experimental models. In this sense, the studies carried out using different animal models (mice, fish) revealed an important effect on the neurotransmission induced by MC-LR (Wu et al., 2016; Qian et al., 2018; Shin et al., 2018; Wang et al., 2018), together with an enhancement in oxidative stress in mice (Shin et al., 2018; Wang et al., 2018), and cytoskeleton disruption in the case of rats (Zhang et al., 2018) (Fig. B).

\subsection{Neurotoxicological in vitro studies performed with microcystins}

Table 2 shows the different in vitro assays performed with MC-LR and some other congeners in different neuronal cell lines and primary cultures. The in vitro studies are relatively recent, comprising a range of ten years (2009-2018) (Table 2). This fact demonstrates the importance that MCs have lately acquired concerning their neurotoxicity nowadays. Thus, it is possible to find different studies carried out in permanent cell lines (PC12, BV-2, N2a, GT1-7, and SH-SY5Y) and in several primary cell cultures. It is also important to remark that all the toxins used in these studies are commercial standards with a purity $>95 \%$, which guarantees that the results reported are 
due to the MC itself and not to other potential bioactive compounds that can be present in cyanobacterial extracts (Falconer, 2007). Furthermore, it is important to highlight that no studies have been performed using extracts in vitro.

2.1.1 Cell viability studies after exposure to MCs

Cell death caused by MCs in neuronal cells has been studied by different assays. Occupying an important place in these studies are the cytotoxicity assays. As it can be observed in Table 2, the 3-(4,5-dimethylthiazol-2-yl)-2,5-diphenyltetrazolium (MTT) reduction assay, the lactate dehydrogenase $(\mathrm{LDH})$ release assay, and the cell counting kit-8 (CCK-8) test have been used to explore the cytotoxicity of MC congeners in several neuronal cell lines. In primary cell lines, Feurstein et al. (2009) found that MCLF, -LW, and -LR induced a concentration-dependent decrease of primary murine WBC when exposed to $0-5 \mu \mathrm{M}$ MCs for 48 hours, being MC-LF the most potent toxin. Rozman et al. (2017) also evidenced the different cytotoxicity induced by the MC-LW and MC-LF congeners in primary rat astrocytes exposed to 0-10 $\mu \mathrm{M}$ MCs for 24 hours. However, these authors did not find any significant reduction of viability in cells exposed to MC-LR. On the contrary, Cai et al. (2015) found a concentration-dependent reduction of cell viability in primary hippocampal neurons, although the MC-LR concentrations used were higher $(0-30 \mu \mathrm{M})$ than in the previous study. Despite this, Li et al. (2015a) used lower concentrations of MC-LR $(0-3 \mu \mathrm{M})$ in the same cellular model, remarking that they only found a reduction of cell viability at the highest concentration assayed after 48 hours of exposure. These same authors also evaluated the LDH release, showing that this release increased with the MC-LR concentration. However, Zhang et al. (2018) observed that only the highest concentration (10 $\mu \mathrm{M}$ MCLR) induced a significant loss of viability in SH-SY5Y cells exposed for 24 hours. This 
fact would indicate that the cellular model could play a role in the MC-LR toxicity,

187 being more sensitive those cells derived from the hippocampus.

Concerning permanent cell lines, different patterns have been observed. Thus,

Takser et al. (2016) found that murine microglial BV-2 cell line suffered a decrease in cell viability when exposed to $0-10 \mu \mathrm{M}$ MC-LR during 72 hours. Furthermore, these same authors revealed that the $\mathrm{N} 2 \mathrm{a}$ cell line presented an even more significant reduction of viability after 72 hours of exposure, establishing possible differences between cells from different origins. The results obtained by Ding et al. (2017) were reduction of viability in GT1-7 cells exposed up to $1 \mu \mathrm{M}$ MC-LR during 48 hours. In this study, the MC-LR concentrations used were pretty lower than those used by the rest of the authors. Thus, the main target of MC-LR in the nervous system seems to be the limbic system, since cells from hypothalamus and hippocampus have proven to be the most sensitive.

\subsubsection{Effects of MCs in different proteins}

Many of the presented studies deal with the fact that MCs need to enter the neuronal cells to exert their toxic effects. It is well known that MCs use OATP/Oatp to get into cells. In this sense, Feurstein et al. (2009) stated that primary murine whole brain cells (WBC) presented, at least, five Oatps, and demonstrated the role of these transporters in the toxicity induced by different MC congeners. Lately, the same authors employed primary murine neurons and cerebellar granule neurons (Feurstein et al., 2010; 2011), and demonstrated that MC-LF, -LW, and -LR produced a significant PPs inhibition at different concentrations, being MC-LF the most potent toxin and MC-LR the least one. Concerning MC-LR, Meng et al. (2011), in differentiated rat 
neuroendocrine PC12 cells, and Zhang et al. (2018), in human neuroblastoma SH-SY5Y

211 cells, found that this toxin inhibited the PP2A in a concentration-dependent manner.

212 However, MCs uptake has been also shown by imaging techniques. Thus, Rozman et al.

213 (2017) confirmed the uptake of different MCs congeners by immunochemistry in

214 primary rat astrocytes. Moreover, Ding et al. (2017) and Zhang et al. (2018) used the western-blot technique to demonstrate the penetration of MC-LR in hypothalamic neuronal mouse cells 1-7 (GT1-7) and SH-SY5Y cells, respectively, analyzing the PP1 and PP2A catalytic subunits, which appeared reduced as the toxin concentration increased.

Inhibition of PP2A activity has been described as the main toxic mechanism of MCs (Yoshizawa et al., 1990), which is related to the selective destruction of microtubules, leading to cell death. Different proteins are involved in cellular organization, and among them, one of the most relevant is Tau. This abundant microtubule-associated protein which main function to stabilize the microtubules assembly, is less effective the more phosphorylated Tau is (Buée and Delacourte, 2001), being associated with microtubule dysfunction and cell death (Feurstein et al., 2011). These last authors found, in primary murine cerebellar granule neurons (CGNs), that MC congeners induced Tau hyperphosphorylation at lower concentrations than the needed for PP2A inhibition, which could evidence that specific proteins from the nervous system display more sensitive response to MCs. However, these concentrations did not lead to significant cell death by apoptosis (activation of caspase-3/7 was absent); although disruption of the neurite network was observed, which is in agreement with the findings of Rozman et al. (2017) in primary rat astrocytes. Meng et al. (2011) also established the connection between the inhibition of PP2A and Tau protein hyperphosphorylation in differentiated PC12 cells. Furthermore, these authors studied 
afterwards Tau phosphorylation through the p38-mitogen-activated protein kinase (p38MAPK), reporting that MC-LR exposure induced p38-MAPK activation, although at higher concentrations than those required for the inhibition of PP2A. Thus, they established that this could be an indirect mechanism of Tau hyperphosphorylation. In addition, they also found that the heat-shock protein 27 (HSP27), responsible of actin cytoskeleton remodeling, was also increased due to the activation of p38-MAPK, contributing to the cell disruption caused by MC-LR. Related to this, Meng et al. (2013) demonstrated that the previously described activation of p38-MAPK by MC-LR in PC12 cells was downstream of ROS-dependent signaling cascades. More recently, Zhang et al. (2018) confirmed the activation of the p38-MAPK in SH-SY5Y cells exposed to MC-LR. Moreover, these authors also found that MC-LR activates the c-Jun $\mathrm{N}$-terminal kinase (JNK), a protein associated with the induction of cell death by apoptosis. Besides, MC-LR induced the phosphorylation of the glycogen synthase kinase-3 (GSK-3 $\beta$ ), contributing to the dissociation of the regulatory subunit B55 $\alpha$ from the PP2A and its degradation, facilitating Tau hyperphosphorylation.

2.1.3 Involvement of $\mathrm{MCs}$ in the $\left[\mathrm{Ca}^{2+}\right] \mathrm{i}$ levels:

Intracellular calcium $\left(\left[\mathrm{Ca}^{2+}\right]_{\mathrm{i}}\right)$ levels are crucial for cell survival. In this sense, Ding et al. (2001) indicated that MC-LR is implicated in $\mathrm{Ca}^{2+}$ release from mitochondria and the activation of $\mathrm{Ca}^{2+} /$ calmodulin-dependent protein kinase, which triggers cell death by apoptosis in hepatocytes. Thus, Cai et al. (2015) found a concentration-dependent $\mathrm{Ca}^{2+}$ mobilization in primary hippocampal neurons exposed to 0-30 $\mu$ M MC-LR. These authors demonstrated that the increase of $\left[\mathrm{Ca}^{2+}\right]_{\mathrm{i}}$ levels could be due mainly to its mobilization from the endoplasmic reticulum. Mitochondria seemed not to play an important role in the cascade of $\left[\mathrm{Ca}^{2+}\right]_{\mathrm{i}}$. This fact is in agreement 
with the results obtained in the previously described MTT assays (Feurstein et al., 2009, 2011; Takser et al., 2016), since authors described a concentration-dependent loss of cell viability, but only a few observed significant differences against the control groups. In addition, $\mathrm{Li}$ et al. (2015a) reported that MC-LR participated in the activation of the $\mathrm{Ca}^{2+} /$ calmodulin-dependent protein phosphatase, calcineurin $(\mathrm{CaN})$, through the mobilization of $\left[\mathrm{Ca}^{2+}\right]_{i}$ levels, leading to the activation of an apoptotic caspase cascade. In this sense, Feurstein et al. (2011) found that MC-LF and MC-LW induced a concentration-dependent increase of caspase-3/7 activity in primary murine CGNs. Furthermore, Rozman et al. (2017) also observed apoptosis in primary rat astrocytes exposed to different MC congeners. However, these authors did not propose any theory about the apoptosis pathway. These findings could be in agreement with the reports of Cai et al. (2015) and Li et al. (2015a) concerning $\mathrm{Ca}^{2+}$ mobilization and apoptosis.

Summarizing, MC-LW and -LF have proven to exert higher neurotoxic effects in vitro than MC-LR. However, since MC-LR is the most abundant congener in nature, all the studies presented in Table 2 have been carried out using this cyanotoxin. The way these toxins reach the nervous system is not fully elucidated yet, although several authors demonstrated the participation of OATPs/Oatps in their transport, together with an inhibition of the protein phosphatase. Once inside neuronal cells, MCs have shown to disrupt several proteins participating in the cellular structure (PP2A, Tau, p38 MAPK, HSP27, GSK-3 $\beta$, etc.), inducing cytoskeleton remodeling and cell death. In addition, cellular disruption has been demonstrated as well by cytotoxicity and apoptosis assays. Both mechanisms could be associated with the increment of $\left[\mathrm{Ca}^{2+}\right]_{i}$ levels. However, it is noteworthy that cells affected by MCs are mainly those present in the limbic system, pointing out this system as a possible target for MCs. 
283

284

285

286

287

288

289

290

291

292

293

294

295

296

297

298

299

300

301

302

303

304

305

306

\subsection{Neurotoxicological in vivo studies performed with microcystins in aquatic}

animals

Several works have investigated so far MCs potential neurotoxicity in different fish species, mainly in zebrafish (Danio rerio) (Table 3). The first studies reporting the chronic effects of dissolved MC-LR on the fish behavior were performed by Baganz et al. (1998, 2004). Behavioral studies are important to establish the lowest level of disturbance. In this sense, these authors observed that MC-LR induced a decrease of daytime and nighttime activity in D. rerio after their exposure to high concentrations, while at low ones, that reduction at night was compensated by a rise in their daytime activity. On the contrary, at high concentrations, Leucaspius delineatus reduced its activity during the daytime, increasing at night, whereas a rise was reported during both day and night at low concentrations. These compensative responses could be explained as an escape strategy or as a consequence of some changes in the spatial orientation to deal with alterations in the medium conditions, represented by the presence of MCs. However, the decreased motility observed at high MC-LR concentrations may be interpreted as an attempt to save energy, needed maybe to biotransform the toxin, which is a possible reason why glutathione-S-transferase (GST) activity appeared enhanced. L. delineatus showed greater sensitivity than D. rerio, as it responded earlier and for a longer period of time (Baganz et al., 2004).

Neurotoxicity of pure MC-LR at the proteomic level was firstly demonstrated in zebrafish brains after chronic exposure (30 days) by Wang et al. (2010) and in developing zebrafish larvae after 96 hours post-fertilization exposure by $\mathrm{Li}$ et al. (2011b). Furthermore, chronic exposure seemed to interfere concomitantly with signal transduction, leading to apoptosis, transport and protein degradation, and increasing the 
PP activity at higher toxin concentrations by PP2C $\alpha 2$ overexpression (Wang et al., 2010). Li et al. (2011b) suggested a potential involvement of creatine kinase (CK) and dihydropyrimidinase-like 2 (DRP2) in the neurotoxicity induced by MC-LR, which were upregulated in larvae of zebrafish. The CK seemed to be correlated with increased energy requirements, and DRP2 with axonal outgrowth, cell migration, neuronal growth, and pathfinding. In this sense, a decreased expression of DRP2 has been reported in schizophrenia, Alzheimer disease, the Down syndrome, and affective disorders (Johnston-Wilson et al., 2000; Lubec et al., 1999).

Pavagadhi et al. (2012) studied the influence of sub-lethal concentrations of dissolved MC-LR and MC-RR (0-10 $\mu \mathrm{g} / \mathrm{L})$ on several oxidative stress parameters in the brain of zebrafish adults such as GST, glutathione peroxidase (GPx), glutathione reductase (GR) and superoxide dismutase (SOD) activities. Generally, most of the parameters followed a bell-shaped curve for both toxins, with peaks at different concentrations. Most of these enzyme activities rose at lower concentrations and decreased at the highest ( 5 and $10 \mu \mathrm{g} / \mathrm{L}$ ). However, discrepancies between GPx and GR activities were observed as the effects of MC-LR were more prominent in GPx activity while GR activity was more enhanced after exposure to MC-RR. These variations could probably be due to the biochemical adaptive response of the organisms to MCs exposure depending on their specific toxicity.

A more recent study has shown that accumulation of MC-LR in zebrafish larvae led to hypoactivity with alteration of the cholinergic system, showed by decreased dopamine (DA) and ACh levels, and increased AChE activity, which could also yield to hypoactive muscular contraction and behavioral responses ( $\mathrm{Wu}$ et al., 2016). In addition, and similar to previous works, their proteomic analysis suggested that this 
neurotoxicity could be related to neuron maturation, axon growth, and cytoskeleton regulation. Nevertheless, if these effects induced by MC-LR could be of parental transmission or not was later clarified by chronic exposures of adult zebrafish to environmentally relevant concentrations of MC-LR (1-25 $\mu \mathrm{g} / \mathrm{L})$, demonstrating, for the first time, the toxin accumulation and developmental neurotoxicity in offspring (Wu et al., 2017). The mechanisms by which these transgenerational effects are exerted could be by interrupting the neuronal development and/or by hampering the neurotransmitter systems (as shown by decreases in DA and serotonin levels, and in AChE activity). Moreover, exposure of zebrafish embryos to similar concentrations of MC-LR for 90 days led to several histopathological damages in the brain (Yan et al., 2017). Despite lacking the clear cerebral cortex of higher vertebrates, fish cerebra rule complex behavior such as escaping from predators, swimming, and feeding modulation. Thus, it would make sense that the ultrastructural changes detected in this study could have impaired the function of nerve fibers in zebrafish exposed to MC-LR. These authors suggested that the disruption of the GABA pathway might be also implicated in the mechanism of MC-LR-induced neurotoxicity (Yan et al., 2017). The stress response in fish is regulated by the hypothalamic-pituitary-adrenal (HPI) axis, which modulates cortisol levels (Yan et al., 2012; Chen et al., 2016), having both important functions in behavior and development. In addition, cross-talk among the nervous, endocrine, and immune systems have been previously reported in fish (Steenbergen et al., 2011). In this sense, Liu et al. (2015), Zhao et al. (2015b), Su et al (2016) and Chen et al. (2018) observed altered transcription of genes along the HPI axis in zebrafish, mostly of gonadotropin hormone, which is also a modulator of the reproductive behavior. Moreover, Chen et al. (2018) observed, for the first time, that MC-LR altered cortisol 
355 levels. Thus, neurotoxicity of MCs could have an impact on endocrine disruption, 356 influencing the autonomic nervous system activity.

Apart from D. rerio and L. delineatus, the effects of pure MC-LR have been also described in whitefish (Coregonus lavaretus). Thus, MC-LR induced an up-regulation of the protein expression of the glial fibrillary acidic protein ( $g f a p$ ), suggesting neuronal toxicity, although no changes were observed in the expression of MiR124-3p (Florczyk et al., 2018). Thus, after damage to the central nervous system (CNS), astrocytes normally act by reaction with a quick synthesis of gfap, whereas the most abundant microRNA in the nervous system, MiR124, is involved in brain development and neuronal regulation. These results provide new information to understand the role of microRNAs in the mechanisms of MC-LR-induced neurotoxicity, and they suggest that MiR124-3p cannot be considered as a biomarker of MC-LR-induced brain injury. In agreement with the findings in vitro, Fischer et al. (2005) demonstrated, in oocytes of the frog Xenopus laevis, that human OATP1A2, expressed in endothelial cells of the BBB, mediates the transport of MC-LR into the brain. Furthermore, they do not rule out that other transporters, as Oatp1c1/OATP1C1, may be also involved in this function.

Studies conducted with lyophilized cyanobacterial cultures containing MCs are scarcer compared to those performed with pure MCs. In this regard, Fischer and Dietrich (2000) detected, for the first time, MC protein-adducts in the brain of carp (Cyprinus carpio) acutely exposed to a freeze-dried culture of $M$. aeruginosa containing MC-LR, although no pathological changes were observed in brain. Later, Gélinas et al. (2012) studied several antioxidant parameters and AChE activity in brain after exposure of juvenile rainbow trout (Oncorhynchus mykiss) to crude extract from $M$. aeruginosa 
containing MC-LR $(0-5 \mu \mathrm{g} / \mathrm{L})$ for 96 hours. No significant changes were observed in 380 GST activity or in LPO levels, and a decrease in AChE activity only occurred at the highest concentration assayed. However, an evident reduction of the protein-bound phosphate at all concentrations assayed was found, which could lead to a diminishment of protein phosphatase activity. Contrarily, after acute exposure to MC-LR isolated from $M$. aeruginosa by dissolving the toxin in water and intraperitoneally, Kist et al. (2012) demonstrated that zebrafish brain suffered an increase of AChE activity only when dissolved, being relevant as its over-expression can promote apoptosis. According to the authors, AChE effect in brain may be indirectly caused by the calcineurin, present in the zebrafish brain. In agreement with Gélinas et al. (2012) but in discordance with Kist et al. (2012), Qian et al. (2018) reported a decrease in AChE levels in larvae of the same species after exposure to a M. aeruginosa culture containing MC-LR. This could have, as a consequence, a reduction of the gene transcription of ache, together with a concentration-dependent decline of the nicotinic acetylcholine receptor a-7 (chrna7) swimming speed. Besides, neuronal development and differentiation effect, impaired synapse formation, astroglia effect and a concentration-dependent reduction of dopamine were observed; together with an effect of the dopaminergic system in the zebrafish larvae. Differences in locomotion were observed in the embryos of the same species exposed to Planktothrix agardhii containing MC-LR and MC-YR, and to $M$. aeruginosa containing MC-LR (Jonas et al., 2015).

The neurotoxic effects of pure MC-RR on aquatic organisms have been far less investigated in comparison to pure MC-LR, and they are somehow contradictory. Although Cazenave et al. (2006) reported the brain of Corydoras paleatus as the most affected organ after exposure to dissolved MC-RR by increases on lipid peroxidation 
(LPO) levels and decreases in GST activity, they were not able to detect the toxin in brain of this species (Cazenave et al., 2005). In agreement with this study, Cazenave et al. (2008) found that exposure of Jenynsia multidentata to MC-RR led to oxidative stress and altered locomotor activity. The hyperactivity observed at low doses suggests an escaping from the stress of MC-RR exposure, while the reduced swimming activity together with the increased detoxification at higher doses may represent a reallocation of energy (Cazenave et al., 2008), response that was obtained as well in previous studies carried out, in this case, with MC-LR (Baganz et al., 1998, 2004). In addition, fish hyperactivity could be also a result of the alert reaction caused by the presence of MC$\mathrm{RR}$ in the fish brain, showing for the first time that MC-RR, although being more hydrophilic than MC-LR, is able to cross the BBB in J. multidentata (Cazenave et al., 2005).

Up to date, only one study has evaluated the effect on the fish brain after exposure to MC-RR extracted from freeze-dried crude algae (Okogwu et al., 2014). Carassius auratus showed a reduction of the total antioxidant capacity in brain combined with a hypoxia-reoxygenation process. A decrease in the SOD and GPx levels was observed during reoxygenation, as myoglobin and neuroglobin were upregulated both during hypoxia and reoxygenation, which might help to the detoxification process of reactive nitrogen species and ROS, being of use in the fight against oxidative stress.

Generally, the effects of both pure MCs and those from cyanobacterial blooms have been shown in the central and peripheral nervous systems of several fish species, although different sensitivity was observed among them. Main observations were changes in behavior, oxidative stress parameters, genes involved in energy requirements and axonal growth, and in cholinergic and dopaminergic systems, together with 
disruption of the GABA pathway. These, together with MC-LR accumulation in fish

429 brain and offspring, could explain the observed transgenerational changes and developmental neurotoxicity of MC-LR. Compensation responses in the circadian rhythm of fish have been also reported, with a generally increased activity at low doses and the opposite at high doses. In any case, the neurotoxic effects of MC-RR have been less investigated than those of MC-LR, in spite of being one of the most common congeners. More studies are needed to clarify the ability of MC-RR to cross the BBB in other aquatic species, given its differential detection in the two fish species studied. Moreover, comparative studies of the neurotoxicity induced by exposure to pure MCs or to cyanobacterial extracts could help to clarify MCs crossing of the $\mathrm{BBB}$ in aquatic organisms. The potential energy reallocation in the brain of MCs-exposed organisms also deserves further research, together with its effect on the endocrine system because of the damage caused in the HPI axis. Furthermore, investigating the inhibition of OATP-mediated MCs transport could be of interest to provide an option for neurotoxicity prevention.

\subsection{Neurotoxicological in vivo studies performed with microcystins in terrestrial} animals neurotoxic potential MCs can exert in terrestrial animals (Table 4). Many of them have been performed in nematodes (Li et al., 2009a, b; Ju et al., 2013, 2014; Moore et al., 2014; Saul et al., 2014), mice (Shin et al., 2018; Wang et al., 2018) and rats (Li et al., 2012a, b; Wang et al., 2013; Li et al., 2014; Li et al., 2015b; Zhang et al., 2018) using pure MC congeners, mainly MC-LR. This is probably due to the fact that, although a total of 246 variants of MCs have been described so far (Meriluoto et al., 2017), MC- 
452 LR has demonstrated to be one of the most toxic structural variants, contributing on 46-

$45399.8 \%$ of the total MCs in natural waters (Ufelmann et al., 2012). Considering that

454 cyanotoxins are not found isolated in nature but together with other substances

455 produced in cyanoblooms, very few studies have been conducted using cyanobacterial

456 biomass cultures or their extracts for terrestrial animal exposure (Pašková et al., 2008;

457 Wang et al., 2008; Ju et al., 2014; Zhao et al., 2015).

Approximately a third part of these studies have been performed using the nematode Caernorhabditis elegans as experimental model and almost under the same experimental conditions. This may be due to its short lifespan and its usage as an environmental bio-indicator, reacting to a variety of environmental stimuli (Mutwakil et al., 1997; Graves et al., 2005). Moreover, C. elegans only presents 302 neurons, and the complete writing diagram for chemical and electrical connections is available (White et al., 1986). It is also important to highlight that, as a liver-lacking animal, the neurotoxic effects were more obvious (Saul et al., 2014).

The first study performed in C. elegans exposed to pure MC-LR reported a decrease in the chemotaxis to $\mathrm{NaCl}$ and diacetyl and in the thermotaxis in a concentration-dependent manner, suggesting damage on the corresponding sensory neurons ( $\mathrm{Li}$ et al., 2009a). These effects were probably caused by the disruption of ASE and AWA sensory neurons, responsible for the chemotaxis, while an impairment of sensory neurons AFD and interneuron AIY, responsible for the thermotaxis, was reported as well (Satterlee et al., 2001; Li et al., 2009a), demonstrating a genetic control of these neurons by MC-LR. According to these results, Li et al. (2009b) reported a significant decrease of lifespan and body size after exposure to the highest concentrations of MC-LR assayed, together with a decrease of the head thrash and body 
bend after exposure to low concentrations. Moreover, effects on generation time, brood

477 size and stress parameters were also observed. Ju et al. (2013) reported that low concentrations of MC-LR produced a significant decrease of body bend and head thrash frequency after 8 hours of exposure while, after 24 hours, all concentrations did, showing a time-dependent response. Moreover, the morphology effects caused by different neurotransmitters after exposure to MC-LR were evaluated and, although no structural alterations were observed in the cholinergic, serotonergic, dopaminergic and glutamatergic systems, a GABAergic neuronal loss and aberrant neuronal morphology were observed after exposure to the highest concentration of MC-LR. Furthermore, this study revealed that MC-LR induced 1) adverse effects on the transportation and location of GABA altering unc-47, unc-46, and unc-30 gene expression and 2) alteration of both the inhibitory and excitatory GABA receptors decreasing unc-49 and exp-1 expression levels. This effect on GABA could lead to the effects previously observed in the locomotor behavior. In agreement with these results, Ju et al. (2014) reported a significant decrease of different autonomic functions, such as body bend and touch response, move length, pharyngeal pumping frequency and defecation period interval (only after 24 hours of exposure to the highest concentration of MC-LR). These authors demonstrated, exposing to a filtrate of $M$. aeruginosa culture containing MCs, that the response opposed to the one obtained with pure MC-LR, observing an increase in locomotive behavior and pumping activity and no alteration of sensory functions. These differences could be due to 1) the higher concentration present in the biomass compared to pure MC-LR used (300 vs $100 \mu \mathrm{g} / \mathrm{L}$ ), 2) the presence of other active substances, and 3) the presence of several MC congeners, such as MC-RR and MC-YR. In addition, 499 Moore et al. (2014), demonstrated alteration to diacetyl after exposure to MC-LR, 500 showing an alteration of the function of the AWA sensory neuron. However, the effects 
on the chemotaxis to benzaldehyde after exposure to MC-LR, regulated by AWC neurons, was not observed, highlighting the fact that AWC and AWA neurons act as independent targets. Moreover, these effects were compared to the ones caused by the exposure to MC-LF, suggesting a more potent effect by MC-LF than MC-LR. Up to date, only this neurotoxicity study has been carried out with this congener in nematodes, despite MC-LF is transported more efficiently into the neurons (Feurstein et al., 2010). Furthermore, Saul et al. (2014) obtained a significant decrease in all life trait variables, measured at different periods of the nematode life cycle, only at the highest concentration of MC-LR assayed. They investigated widely the variation in the gene expression, reporting an enhancement of 125 , among which was unc-30, related to the GABAergic response, and a decrease of 76. Although these results may seem contradictory to the ones obtained by Ju et al. (2013), as they described a diminish of unc-30 gene expression, it is important to highlight that the duration of the stress exposure is essential for their regulation, being the possible cause for their discordance (Nadal et al., 2011). Moreover, Saul et al. (2014) also reported a down-regulation in let7 expression, which could play a role in the development and the reproductive processes, contributing, therefore, to the effects observed in the brood size and growth. Their results manifested that many of the affected genes by MC-LR are involved in neurogenesis, signaling or neurological behavior processes, reinforcing those results previously obtained by Li et al. (2009a) and Ju et al. (2013), where MC-LR played an important role in the neuromodulating action.

In general, the different behavioral studies agree that MC-LR produced a decrease in autonomic (body bend, head thrash, move length, pharyngeal pumping, touch response) and sensory (chemical, thermal) functions reflecting an alteration in the nervous system functions to generate appropriate behaviors from sensory signals in 
nematodes (Li et al., 2009a;b; Ju et al., 2013, 2014; Moore et al., 2014). Therefore, MC-

527 LR at environmentally relevant concentrations, could affect the nervous system regulation to receive, process, integrate and interpret sensory signals, as suggested by the gene expression results (Li et al., 2009a;b; Ju et al., 2013; Saul et al., 2014; Hu et al., 2016). It is important to point out that not always a variation in the gene expression can be translated to a change in protein levels, being required complementary studies in order to assure the neurotoxic role of this toxin (Saul et al., 2014). Although previous studies confirmed the suitability of the $C$. elegans test as a neurotoxicity screening test for MCs (Ju et al., 2014), it should be taken into account that this experimental model is much simpler than the mammals-nervous system.

The only neurotoxicity study performed in birds was carried out in Japanese quail exposed to Microcystis biomass containing MC-LR, MC-RR, MC-YR and MCssimilar compounds (Pašková et al., 2008). This study focused on the determination of oxidative stress, where a significant enhancement was reported in cytochrome P-450dependent 7-ethoxyresorufin O-deethylase (EROD) levels in the brain after acute and

541 sub-chronic exposure at medium concentrations of MCs. The LPO levels were also 542 enhanced after acute and sub-chronic exposure, so did the GSH levels, decreasing, nonetheless, after acute exposure. Howbeit, no significant changes were observed in

544 GST activity in this organ. In general, a rise in the oxidative stress parameters was described by these authors in brain (Pašková et al., 2008). Oxidative stress as a mechanism of toxic action of MCs has been widely studied in other organs such as liver or kidney in different species (Li et al., 2003; Jos et al., 2005; Skocovska et al., 2007;

548 Weng et al., 2007; Prieto et al., 2009); however, these investigations are very scarce in 549 brain. The increase of ROS could be involved in the mitochondrial dysfunction and 
550 activation of calpain and $\mathrm{Ca}^{2+/}$ calmodulin-dependent protein kinase II (Ding and Nam

551 Ong 2003), generating damage in the brain structure and neurological functions.

Mice exposed to pure MC-LR showed differences in the effects on hippocampus and cortex after oral exposure by drinking water with 1-40 $\mu \mathrm{g} / \mathrm{L} \mathrm{MC}-\mathrm{LR}$ for a year 554 (Wang et al., 2018). Histopathological changes were observed in the hippocampus (bright eosinophil-like angular shape and nuclear fragments) and in the cortex (shrunken bodies and pyknotic nuclei) dose-dependently. Likewise, MC-LR produced different impacts on mRNA transcription genes and in their protein expression (ATP6, COX3, CYTB, DNA polymerase $\mathrm{\gamma}$ (POLG), mitochondrial single-stranded DNA-binding protein (mtSSB) and mitochondrial transcription factor A (TFAM)), mainly affecting the hippocampus. In accordance with these results, Shin et al. (2018) described a dosedependent neuronal loss in the same hippocampal cells due to several morphological changes, but in this case, after exposure to a cyanobacterial extract containing MC-LR. Moreover, several behavioral studies demonstrated memory impairment after Morris water maze (MWM) and passive avoidance tests. However, these effects were only observed after exposure to $4 \mu \mathrm{g} / \mathrm{mL}$ MC-LR, suggesting that the neuronal loss is not the main cause for these toxic effects in mice. After exposure to the same doses, no effects on spatial working and visual recognition memory were detected by Y-maze and novel object recognition tests, respectively. These effects were patent only in non-transgenic (non-Tg) mice compared to those overexpressing glutathione peroxidase (GPx Tg). Besides, in non-Tg group, these authors observed significant changes in oxidative stress

571 biomarkers such as increased protein oxidation, LPO and ROS, together with a decrease 572 of the GSH/Glutathione disulfide (GSSG) ratio. Moreover, the rise in SOD enzyme 573 activity was more evident in non-Tg compared to the increase observed in GPx-1 Tg, while the enhancement of GPx enzyme activity was more visible in this last group of 
mice. Furthermore, no proinflammatory tumor necrosis factor- $\alpha$ (TNF $\alpha)$ and allograft inflammatory factor-1 (Iba1) levels were affected after the MC-LR exposure. All of the results obtained in this study suggest that memory impairments in mice exposed were due to oxidative stress in spite of by neuroinflammation process, which could be confirmed by the enhancement of nuclear factor erythroid-derived 2 (Nrf2) observed in both exposed groups. In addition, the reduced responses of GPx-1 Tg compared to nonTg mice suggest a possible prevention of memory impairment by compounds implied in antioxidant activity (Shin et al., 2018).

Furthermore, it is important to highlight that, although not being neurotoxicological studies per sé, some studies exposing mice to pure MC-LR have proven its capacity to cause effects in the HPI axis at hypothalamic level, altering the neurohormonal control of reproduction (Wang et al., 2012; Xiong et al., 2014; Chen et al., 2016).

In rats exposed to MC-LR after infusion into hippocampus presented longer periods of time searching the platform and shorter swimming distance in the target zone, but no significant differences in swimming speed were appreciated compared to the control group ( $\mathrm{Li}$ et al. 2012a). This would point out the spatial learning and memory impairment caused by the exposure to the toxin. Furthermore, some neuronal injury was observed by shrunk nuclei and cellular edema or dissolved cell organelles, diminishing significantly the number of CA1 pyramidal cells in the hippocampus. Nonetheless, after exposure to the lowest dose, some morphological changes were appreciated in the neurons, like swollen and degranulated endoplasmic reticulum or puffed periplast. In fact, a more significant rise in oxidative stress parameters was reported after exposure to the highest concentration (LPO, CAT, GPx, and SOD) versus 
the lowest (LPO and CAT). In agreement with these results, Li et al. (2012b) reported that chronic exposure produced neither changes in intake, body weight and overall mobility, nor visual and locomotor deficits, although they demonstrated the presence of this toxin in brain. However, treated rats did take longer to find the platform, mainly over the late days, spending less time in the target zone, which implies effects on spatial learning and memory as well. This impairment was also confirmed by the degeneration and apoptosis of hippocampal cells in rats exposed to MC-LR for 50 days. Furthermore, the authors observed the presence of proteins involved in neurodegenerative diseases such as septin 5, a-internexin and a-synuclein, and a PPs inhibition after exposure to 10 $\mu \mathrm{g} / \mathrm{kg}$ MC-LR, which may lead to Tau hyperphosphorylation, implied in the generation of Alzheimer's disease. This is the first scientific study correlating MC-LR exposure to an age-associated neurodegenerative disorder.

Additionally, Wang et al. (2013) reported a significant PPs activity enhancement after exposure to pure MC-LR in rats, in disagreement with the results obtained by Li et al. (2012b). This effect could be the cause for the reduction, at all concentrations, of the phosphorylation of GSK-3 $\beta$ in the hippocampus and, consequently, for the described long-term potential concentration-dependent effects, leading to a loss of neuronal plasticity. Moreover, this study showed, for the first time, the prevention of the neurotoxic effects caused by MC-LR by simultaneous treatment with a GSK-3 $\beta$ inhibitor.

In agreement with Li et al. (2012a, b), an investigation of the effects of MC-LR on learning and memory ability in rats was performed by Li et al. (2014), obtaining that the rats exposed to the highest dose presented prolonged escape latencies on the third day of training, while those exposed to lower doses had shorter frequencies entering the 
enlarged platform. Despite no significant differences in the number of damaged neurons were observed, an increase of astrocyte cells density in the hippocampus was reported after the exposure to the highest dose. This could be related to the increase of nitrogen reactive species, an inflammatory indicator, reported in the hippocampus at the same dose, playing a role in the central neuron system inflammatory reactions and affecting spatial memory impairment.

The only study evaluating the transmission of the toxic effects of MC-LR in female rats to offspring was performed by Li et al. (2015b). In maternal rats, a decrease in the mean body weight gain was significant only at the highest dose of exposure. Respecting the behavior of the offspring, a significant reduction of the ability in the cliff avoidance test was observed, although no differences were perceived after the surface righting reflex and the negative geotaxis tests. However, no significant alterations in the locomotor activity were observed. In the MWM test, the frequencies in reaching the platform zone decreased dose-dependently in male offspring at all exposure doses, while in the case of female offspring, the diminishment of frequency was produced only after exposure to the highest doses, together with the effects on the swimming speed. Furthermore, although no evident pathological alterations in the hippocampus were observed, a significant increase of LPO and SOD levels were reported in male and female offspring after exposure to the highest dose, and an increase of LPO levels after $5 \mu \mathrm{g} / \mathrm{kg}$ MC-LR exposures only in male subjects.

Recently, Zhang et al. (2018) indicated an accumulation of MC-LR in the hippocampus after 24 hours of injection, causing demethylation of PP2Ac (inhibition of PP2Ac) and phosphorylation of GSK-3 $\beta$ (activation of GSK-3 $\beta$ ). This could lead to the hyperphosphorylation of Tau, being in agreement with Li et al. (2012b) and Wang et al. 
647 (2013). These results confirm the effects obtained, as mentioned above, in the SH648 SY5Y in vitro model in the same study (Zhang et al., 2018). Moreover, going along 649 with the results obtained in the MWM test by Li et al. (2012a, b, 2014, 2015b), a 650 reduction of the swimming distance spent in the target zone was observed as well, in 651 this case, after day 8 compared to day 6, producing, consequently, memory 652 impairments.

Although they represent a more realistic scenario, only two neurotoxicity studies have been carried out with MCs contained in extracts of cyanoblooms. In this sense, Maidana et al. (2006) used the step-down inhibitory avoidance test by injection of MC-

LR containing raw extract. They reported a significant effect on long-term memory and the impairment of its retrieval at both doses assayed, while no significant changes were produced in short-term memory at any dose. Furthermore, using the radial arm maze to test the spatial memory, the number of working and reference memory errors increased only at day 8 of exposure at both concentrations, being probably caused by the accumulation of previous extracts-administrations. Surprisingly, an increase of the time spent to consume all the baits was reported in the same test only at the lowest dose. Moreover, these authors also studied different oxidative stress parameters, obtaining higher GST activity after exposure to the lowest dose compared to the highest. In the case of LPO levels, higher levels were obtained after exposure to the highest MCs dose, although the lower dose also caused lipid peroxidation. These parameters could be the cause for the increase of DNA damage observed after exposure to MCs in the comet assay, corroborating the role of oxidative stress in the neurotoxic effects produced by MC-containing extracts, as was previously demonstrated with pure MCs (Li et al., 2012a, 2015b). In agreement with these oxidative stress results, Zhao et al. (2015a) obtained an increase in the LPO levels in the brain of the pups after maternal exposure 
to MCs-extract, together with a decrease in the GSH levels and in AChE activity in the cerebral cortex. Moreover, although these authors verified the presence of MC-LR in the offspring brains, no changes were obtained in the PP activity after maternal exposure, which would be in disagreement with the PP activity enhancement reported by Wang et al. (2013) and its decrease reported by Li et al. (2012b) and Zhang et al. (2018). This could be due to the experimental subjects since in both cases the parameter was measured in a direct object, the adult rats, versus an indirect object, their pups; or the discordance in the administration route, being, in this case, subcutaneous. Furthermore, similar ultrastructural changes were obtained in brain offspring by Li et al. (2012a). Likewise, an alteration of proteins involved in neurodevelopment was detected as well, in agreement with Li et al. (2012b).

Taken together, all the experiments conclude that MCs both pure and contained in cyanoblooms extracts produced important neurotoxic effects in several species by different exposure routes. Mostly, MCs caused oxidative stress and alteration of biochemical chains that ended up leading to huge effects such as hyperphosphorylation of Tau. In fact, most of them demonstrate the spatial learning and memory impairment by several behavioral tests. Howbeit, very few studies have been performed using other MC congeners besides MC-LR, isolated and contained in the mixture in a cyanobacterial extract, although some of them have demonstrated to exert more severe neurotoxic effects, being the case of MC-LF for instance.

\section{Cylindrospermopsin}

Cylindrospermopsin consists of a tricyclic guanidine group combined with a hydroxylmethyl uracil group (Ohtani et al., 1992). Its structure presents a zwitterionic nature and a low molecular weight (415 Da) (Falconer and Humpage, 2006). This 
cyanotoxin is produced by several cyanobacterial genera such as Cylindrospermopsis, Aphanizomenon, Umezakia, Chrysosporum, and Anabaena, among others (Harada et al., 1994; Banker et al., 1997; Shaw et al., 1999; Schembri et al., 2001) (Fig. C).

Despite being the liver its main target, many other organs such as kidneys, lungs, thymus, marrow bone, adrenal gland, gastrointestinal tract, immune and nervous systems, and heart have been described as potential targets as well (Hawkins et al., 1985; Terao et al., 1994; Falconer et al., 1999; Humpage et al., 2000; Guzmán-Guillén et al., 2015). The most well-known mechanism of action for CYN is the protein and GSH synthesis-inhibition (Terao et al., 1994; Runnegar et al., 1995; Froscio et al., 2003). In addition, due to its ability to enhance ROS production, this toxin can lead to DNA damage, causing cell death by apoptosis (Roos and Kaina, 2006; Gutiérrez-Praena et al., 2011; Puerto et al., 2011; Gutiérrez-Praena et al., 2012; Guzmán-Guillén et al., 2013). Moreover, some studies have demonstrated the importance of its previous metabolic activation by the enzymatic complex cytochrome P-450, since it is able to exert genotoxic potential (Runnegar et al., 1995; Norris et al., 2002; Froscio et al., 2003; Humpage et al., 2005; Zegura et al., 2011; Puerto et al., 2018). As a cytotoxin, these effects could be also caused in the nervous system. Besides, it is important to notice that the chemical structure of $\mathrm{CYN}$ is more alike to neurotoxins than to hepatotoxins, as it was classified at first, not being unexpected for this cyanotoxin to also cause neurological disorders (Kiss et al., 2002). Furthermore, although it is not likely for CYN to cross the BBB by passive diffusion due to its hydrophilic properties (Banks et al., 2009), its low molecular weight might play a role in its entrance to the nervous system. There are some studies pointing out its neurotoxicity in different in vitro and in vivo models, although the mechanisms for which CYN could exert neurotoxic effects in the brain remain unknown. 


\subsection{Neurotoxicological in vitro studies performed with cylindrospermopsin}

Up to date, in comparison with MCs, very few studies have brought to light the potential neurotoxicity CYN can exert (Table 5). Furthermore, most of them have been performed using extracts or cultures of Cylindrospermopsis raciborskii or Aphanizomenon ovalisporum. In this sense, the first study suggesting its neurotoxic effect was performed by Kiss et al. (2002), who exposed CNS neurons of two species of snail, Helix pomatia L. and Lymnaea stagnalis L., to a $C$. raciborskii purified fraction and ATX-a. They suggested that the purified fraction could be CYN, and although it had no direct effect on the membrane of the neurons, it decreased the ACh-induced membrane response, suggesting a neuroactive effect on the cell membrane for the first time. On the contrary, Vehovszky et al. (2013) reported that application of a CYNproducing strain to CNS preparations of $H$. pomatia (at $20 \mathrm{mg} / \mathrm{mL}$ ) did not display the same cholinergic inhibitory effects, although these were observed after exposure to a non-CYN-producing $C$. raciborskii bloom, which authors attribute to some ATX-a like compound.

In the case of CYN, contrary to MCs, there is only one work with pure toxin, performed by Takser et al. (2016). These authors evaluated in vitro the individual and combined effects of CYN, MC-LR and ATX-a, at environmentally relevant low concentrations (10 $\mu \mathrm{M}$ alone and $3.3 \mu \mathrm{M}$ in mixture), in brain cell lines. Their findings revealed that CYN individually and the mixture containing CYN were 3-15 times more potent than the individual toxins, inducing apoptosis and inflammation in murine BV-2 microglia cells and $\mathrm{N} 2 \mathrm{a}$ murine neuroblasts cells. Besides, the latest were more sensitive to the mixture than BV-2 cells, causing a meaningful pro-inflammatory response to $\mathrm{CYN}$ and the mixture, demonstrating that low concentrations of $\mathrm{CYN}$ are 
highly relevant for neurodegeneration. These outcomes could have potential implications in future research on neurodegenerative diseases. Nevertheless, care should be taken in the extrapolation of these in vitro results to in vivo circumstances, including human health effects, mainly concerning the developing brain where there is no BBB yet.

\subsection{Neurotoxicological in vivo studies performed with cylindrospermopsin}

Studies concerning CYN neurotoxicity in vivo are scarce (Table 5), although they provide interesting results. In this regard, White et al. (2007) reported that 7 dayexposure of Bufo marinus tadpoles to whole cell extracts or live cultures of C. raciborskii at 400 or $232 \mu \mathrm{g} / \mathrm{L}$, respectively, appeared to decrease their activity levels, mostly swimming behavior, which could make them more vulnerable to prey, but also be used as an avoidance strategy from visually-oriented hunters. This effect, however, might have been caused by damage in some other organs. It is worth to mention that live $C$. raciborskii cultures contained a mixture of intra- and extracellular CYN, whereas the cell extracts only had extracellular CYN, and they also reported the presence of deoxy-CYN. This work by White et al. (2007) was the first one using amphibians as experimental model, whose changes in behavior gain relevance as they are usually the first indication of sublethal exposure (Henry, 2000), being a possible indicator of CYN neurotoxicity. In agreement with these results, Kinnear et al. (2007), using the same model and conditions, but nearly half the concentrations (200 and 107 $\mu \mathrm{g} / \mathrm{L}$, for the cell extracts and the live cultures, respectively), reported a reduction in the swimming ability and un-coordination in tadpoles of B. marinus. They suggested that it could be due to the disintegration of the brain, as the encephalon had a loosely arranged matrix and brain cells were disintegrated and sometimes necrotic, showing a mix of the 
outer matrix and inner cells, together with general organ failure. Besides, authors also hypothesized that degeneration of the gill epithelia could have led to suffocation, and finally to the consequently reduced activity.

To our knowledge, there are only two studies concerning the neurotoxicity of CYN in fish. CYN was detected by ELISA in the brain of all tilapia fish (Oreochromis niloticus) exposed subchronically (14 days) by immersion to repeated concentrations $(10 \mu \mathrm{g} / \mathrm{L})$ of an A. ovalisporum culture containing CYN and deoxy-CYN (GuzmánGuillén et al., 2015). As a result, a marked increase in LPO levels, and a reduction in AChE activity in tilapia brains was observed, although the inhibition of AChE activity was too low to induce neurological symptoms. In addition, signs of necrosis, vacuolization, chromatin condensation, cytoplasmic edema and mitochondrial swelling were reported as well. Recently, detection of CYN has also been reported in brains of the fish Hoplias malabaricus exposed by a single i.p. injection $(50 \mu \mathrm{g} / \mathrm{kg} \mathrm{b.w.)}$ to purified CYN or to extracts of a CYN-producing strain of C. raciborskii, even 7 and 14 days after exposure (da Silva et al., 2018). In addition, detected CYN levels were higher after exposure to the extracts, which could point out the importance of other compounds in the extract (i.e. lipopolysaccharides) that might also affect CYN crossing of the BBB. Nonetheless, no significant effects were noticed on AChE activity after CYN exposure in any form tested, contrary to the results obtained by Guzmán-Guillén et al. (2015), which could be due to differences in the exposure concentrations and times (subchronic versus acute exposure) or in the fish species, although both studies agree on the rise of LPO levels. Moreover, GSH levels did not vary in H. malabaricus after exposure to CYN, but different responses were obtained for GST activity for extracts and pure CYN. To exert neurotoxic effects, toxins must be transported into cells or interact with 
801

channels or receptors of the cell membrane (Stillwell, 2013), suggesting the interference of other compounds present in the extract (da Silva et al., 2018).

Some neurological symptoms after exposure of alligators (Schoeb et al., 2002) and mice (Saker et al., 2003, Zagatto et al., 2012) to C. raciborskii strains have been attributed to CYN (Poniedzialek et al., 2012). However, it is important to clarify that neither of these studies proved the presence of CYN in those strains, so the reported effects might be due to different compounds present in the extracts or different secondary metabolites, such as STX.

\section{Conclusions}

This review summarizes, as far as we know, the reports available on the scientific literature dealing with the neurotoxicity assays performed in vitro and in vivo to elucidate the toxic effects that MCs and CYN can exert in the nervous system. In the case of MCs, they have proven to cause neurotoxicity by their crossing using the OATPs, which are present in the BBB and in most neural cells, leading to a rise in the $\left[\mathrm{Ca}^{2+}\right]_{\mathrm{i}}$ levels and, therefore, apoptosis. These cyanotoxins have demonstrated to exert neurotoxic effects mostly in the limbic system. In fact, some histopathological studies have described important damages in the hippocampus and in the cortex, together with global biochemical alterations, being especially relevant Tau hyperphosphorylation, characteristic of some neurodegenerative diseases such as Alzheimer's disease. On the other hand, these toxins have proven to cause damage in the hypothalamus as well, having an impact in other systems of the organism such as the reproductive or the endocrine. Furthermore, MCs have exerted a rise in oxidative stress and lipid peroxidation, together with neurotransmission alterations (DA, ACh and GABA levels), leading to autonomic and sensory responses. Thus, MCs not only cause effects in the 
817 CNS but also in the peripheral nervous system. Furthermore, some other minor variants

818 such as MC-LF or MC-LW require attention as well, since both have demonstrated to

819 be even more toxic in neural cells, in spite of being less environmentally abundant.

820 Special attention should be paid to the fact that very little studies have been carried out

821 in vivo using one of the major congeners in nature, MC-RR. In the case of CYN, the

822 number of studies performed is even scarcer, reporting deregulation of some oxidative

823 stress parameters was observed together with alteration of AChE activity, which could

824 be linked to the histological changes observed. Thus, although neurotoxicity

825 mechanisms for CYN are still unknown, it seems to be caused by damage in the CNS.

826 For all mentioned above, further research is required in order to clarify the neurotoxic

827 potential of several MC congeners and CYN, as well as their possible contribution in 828 neurodegenerative diseases.

\section{Acknowledgments}

830 The authors wish to thank the Ministerio de Economía y Competitividad of Spain 831 (AGL2015-64558-R, MINECO/FEDER, UE) for the financial support, and the Junta de 832 Andalucía for the contract of María Gracia Hinojosa (USE-16667). 


\section{References}

Atencio L, Moreno I, Prieto AI, Moyano R, Molina AM, Cameán AM. Acute effects of microcystins MC-LR and MC-RR on acid and alkaline phosphatase activities and pathological changes in intraperitoneally exposed tilapia fish (Oreochromis sp.). Toxicol Pathol. 2008;36:449-58. Doi: 10.1177/0192623308315356

Baganz D, Staaks G, Steinberg C. Impact of the cyanobacteria toxin, microcystin-LR on behaviour of zebrafish, Danio rerio. Water Res. 1998;32:948-52. Doi: 10.1016/S0043-1354(97)00207-8

Baganz D, Staaks G, Pflugmacher S, Steinberg CEW. Comparative study of microcystin-LR-induced behavioral changes of two fish species, Danio rerio and Leucaspius delineatus. Environ Toxicol. 2004;19:564-70. Doi: 10.1002/tox.20063

Banker R, Carmeli S, Hadas O, Teltsch B, Porat R, Sukenik A. Identification of cylindrospermopsin in Aphanizomenon ovalisporum (Cyanophyceae) isolated from lake Kinneret, Israel. J Phycol. 1997;33:613-6.

Banks WA. Characteristics of compounds that cross the blood-brain barrier. BMC Neurol. 2009;9:1-5. Doi: 10.1186/1471-23 10.1186/1471-2377-9-S1-S3

Berry JP, Lind O. First evidence of "paralytic shellfish toxins" and cylindrospermopsin in a Mexican freshwater system, Lago Catemaco, and apparent bioaccumulation of the toxins in "tegogolo" snails (Pomacea patula catemacensis). Toxicon. 2010;55:930 -938. Doi: 10.1016/j.toxicon.2009.07.035

Bittencourt-Oliveira MDC, Piccin-Santos V, Moura AN, Aragão-Tavares NKC, Cordeiro-Araújo MK. Cyanobacteria, microcystins and cylindrospermopsin in public 
drinking supply reservoirs of Brazil. An Acad Bras Cienc. 2014;86:297-309. Doi:

Bláha L, Babica P, Marsálec B. Toxins produced in cyanobacterial water bloomstoxicity and risks. Interdisc. Toxicol. 2009;2:36-41. Doi: 10.2478/v10102-009-00062

Buée L, Delacourte A. Tau Phosphorilation. Neurobiol Aging. 2001;21:315-332. (the Palm Island mystery disease) possibly caused by algal intoxication. Toxicon. Bronger H, König J, Kopplow K, Steiner HH, Ahmadi R, Herold-Mende C, Keppler D, Nies AT. ABCC drug efflux pumps and organic anion uptake transporters in human gliomas and the blood-tumor barrier. Cancer Res. 2005;65:11419-28. Doi: 10.1158/0008-5472.CAN-05-1271

Buratti FM, Manganelli M, Vichi S, Stefanelli M, Scardala S, Testai E, Funari E. Cyanotoxins: producing organisms, occurrence, toxicity, mechanism of action and human health toxicological risk evaluation. Arch Toxicol. 2017;91:1049-130. Doi:

Cai F, Liu J, li C, Wang J. Intracellular calcium plays a critical role in the 874 microcystin-lr-elicited neurotoxicity through PLC/IP3 pathway. Int J Toxicol. $875 \quad$ 2015;34:551-8. Doi: 10.1177/1091581815606352 cyanobacterium Gloeotrichia echinulata. Environ Toxicol. 2007;22:337-339. Doi: $10.1002 /$ tox. 20245 

KL, Shaw GR, Eaglesham GK. Human fatalities from cyanobacteria: chemical and biological evidence for cyanotoxins. Environ Health Perspect. 2001;109:663-8. Doi: 10.1289/ehp.01109663 Wiegand C. Uptake, tissue distribution and accumulation of microcystin-RR in Corydoras paleatus, Jenynsia multidentata and Odontesthes bonariensis: A field and laboratory study. Aquat Toxicol. 2005;75:178-90.

Doi: 10.1016/j.aquatox.2005.08.002

Cazenave J, Bistoni MA, Pesce SF, Wunderlin DA. Differential detoxification and antioxidant response in diverse organs of Corydoras paleatus experimentally exposed to microcystin-RR. Aquat Toxicol. 2006;76:1-12. Doi: 10.1016/j.aquatox.2005.08.011

Cazenave J, Nores ML, Miceli M, Díaz MP, Wunderlin DA, Bistoni MA. Changes in the swimming activity and the glutathione S-transferase activity of Jenynsia multidentata fed with microcystin-RR. Water Res. 2008;42:1299-307. Doi: 10.1016/j.watres.2007.09.025

Chen L, Xie P. Mechanisms of microcystin-induced cytotoxicity and apoptosis. Mini-Reviews Med Chem. 2016;16:1018-31. Doi: 10.1016/j.aquatox.2014.01.021 Chen L, Chen J, Zhang Z, Xie P. A review of reproductive toxicity of microcystins. J Hazard Mater. 2016;301:381-99. Doi: 10.1016/j.jhazmat.2015.08.041 
larvae) of zebrafish. Environ Pollut. 2018;241:540-8. Doi:

$903 \quad 10.1016 / j . e n v p o l .2018 .05 .024$

904 Chorus I, Bartram J. Toxic Cyanobacteria in Water: A Guide to Public Health 905 Significance, Monitoring and Management. E\&FN Spon, London. 1999.

906 Cirés S, Alvarez-Roa C, Wood SA, Puddick J, Loza V, Heimann K. First report of 907 microcystin-producing Fischerella sp. (Stigonematales, Cyanobacteria) in tropical $908 \quad$ Australia. Toxicon. 2014;88:62-66. Doi: 10.1016/j.toxicon.2014.06.010

909 Cordero-Araújo MK, Chia MA, Bittencourt-Oliveira MDC. Potential human health 910 risk assessment of cylindrospermopsin accumulation and depuration in lettuce and 911 arugula. Harmful Algae. 2017;68:217-23. Doi: 10.1016/j.hal.2017.08.010

912 Costa LG, Giordano G, Guizzetti M, Vitalone A. Neurotoxicity of pesticides: a brief 913 review. Front. Biosci. 2008;13:1240-1249.

914 Da Silva RC, Grötzner SR, Moura Costa DD, Garcia JRE, Muelbert J, de Magalhães 915 VF, Neto FF, Ribeiro AO. Comparative bioaccumulation and effects of purified and 916 cellular extract of cylindrospermopsin to freshwater fish Hoplias malabaricus. J 917 Toxicol Environ Health - Part A Curr Issues. 2018;81:620-32. Doi: $918 \quad 10.1080 / 15287394.2018 .1469101$

919 Davis TW, Gobler CJ. Preface for Special Issue on "Global expansion of harmful 920 cyanobacterial blooms: Diversity, ecology, causes, and controls." Harmful Algae. $921 \quad$ 2016;54:1-3. Doi: 10.1016/j.hal.2016.02.003

922 Díez-Quijada L, Prieto AI, Guzmán-Guillén R, Jos A, Cameán AM. Ocurrence and 923 toxicity of microcystin congeners other than MC-LR and MC-RR: A review. Food 924 Chem Toxicol. 2018;125:106-132. Doi: 10.1016/j.fct.2018.12.042 
Ding WX, Shen HM, Ong CN. Pivotal role of mitochondrial $\mathrm{Ca}^{2+}$ in microcystininduced mitocondrial permeability transition in rat hepatocytes. Biochem Biophys Res Commum. 2001;285:1155-1161. Doi: 10.1006/bbrc.2001.5309

Ding WX, Nam Ong C. Role of oxidative stress and mitochondrial changes in cyanobacteria-induced apoptosis and hepatotoxicity. FEMS Microbiol Lett. 2003:220:1-7. Doi: 10.1016/S0378-1097(03)00100-9

Ding J, Wang J, Xiang Z, Diao W, Su M, Shi W, Wan T, Han X. The organic anion transporting polypeptide $1 \mathrm{a} 5$ is a pivotal transporter for the uptake of microcystin-LR by gonadotropin-releasing hormone neurons. Aquat Toxicol. 2017;182:1-10. Doi: 10.1016/j.aquatox.2016.11.005

Duy, T.N., Lam, P.K.S., Shaw, G., Connel, D.W. Toxicology and risk assessment of freshwater cyanobacterial (blue-green algal) toxins in water. Rev. Environ. Contam. Toxicol. 2000;163:113-186. Falconer IR, Humpage AR. Cyanobacterial (blue-green algal) toxins in water supplies: Cylindrospermopsins. Environ Toxicol. 2006;21:299-304. Doi: 10.1002/tox.20194

Falconer IR, Hardy SJ, Humpage AR, Froscio SM, Tozer GJ, Hawkins PR. Hepatic and renal toxicity of the blue-green alga (cyanobacterium) Cylindrospermopsis raciborskii in male Swiss albino mice. Environ Toxicol. 1999;14:143-50.

Falconer IR. Cyanobacterial toxins present in Microcystis aeruginosa extracts-More than microcystins! Toxicon. 2007;50:585-8. Doi: 10.1016/j.toxicon.2007.03.023 Faassen EJ, Lürling M. Occurrence of the microcystins MC-LW and MC-LF in Dutch surface waters and their contribution to total microcystin toxicity. Mar Drugs. 2013;11:2643-54. Doi: 10.3390/md11072643 
Feurstein D, Holst K, Fischer A, Dietrich DR. Oatp-associated uptake and toxicity of 950 microcystins in primary murine whole brain cells. Toxicol Appl Pharmacol. 2009;234:247-55. Doi: 10.1016/j.taap.2008.10.011

Feurstein D, Kleinteich J, Heussner AH, Stemmer K, Dietrich DR. Investigation of microcystin congener-dependent uptake into primary murine neurons. Environ Health Perspect. 2010;118:1370-5. Doi: 10.1289/ehp.0901289

Feurstein D, Stemmer K, Kleinteich J, Speicher T, Dietrich DR. Microcystin congener- and concentration-dependent induction of murine neuron apoptosis and neurite degeneration. Toxicol Sci. 2011;124:424-31.

Fischer WJ, Dietrich DR. Pathological and biochemical characterization of microcystin-induced hepatopancreas and kidney damage in carp (Cyprinus carpio). Toxicol Appl Pharmacol. 2000;164:73-81. Doi: 10.1006/taap.1999.8861 anion transporting polypeptides expressed in liver and brain mediate uptake of microcystin. Toxicol Appl Pharmacol. 2005;203:257-63.

Doi: toxins. Environ Biotechnol. 2014;10:26-43. Doi: 10.14799/ebms246 triggered neuronal toxicity in whitefish does not involve MiR124-3p. Neurotox Res. 2018;241:1-12. Doi: 10.1016/j.envpol.2018.05.024 protein synthesis inhibition and its dissociation from acute toxicity in mouse 

extracts on juvenile rainbow trout (Oncorhynchus mykiss). Comp Biochem Physiol B Biochem Mol Bio. 2012;161:261-267. Doi: 10.1016/j.cbpb.2011.12.002.

Gkelis S, Zaoutsos N. Cyanotoxin occurrence and potentially toxin producing cyanobacteria in freshwaters of Greece: a multi-disciplinary approach. Toxicon. $2014 ; 78: 1-9$. Doi: 10.1016/j. toxicon.2013.11.010 980

Graham JL, Loftin KA, Meyer MT, Ziegler AC. cyanotoxin mixtures and taste-andodor compounds in cyanobacterial blooms from the Midwestern United States. Environ. Sci. Technol. 2010 ;44 :7361-68. Doi : 10.1021/es1008938 soil toxicity testing. Arch Environ Contam Toxicol. 2005;48:490- 494. Doi: 10.1002/tox.10103

987

Gurbuz F, Uzunmehmetoğlu OY, Diler Ö, Metcalf JS, Codd GA. Occurrence of 988

Griffiths DJ, Saker ML. The Palm Island mystery disease 20 years on: A review of research on the cyanotoxin cylindrospermopsin. Environ Toxicol. 2003;18:78-93. microcystins in water, bloom, sediment and fish from a public water supply. Sci Total Environ. 2016;15:860-8. Doi: 10.1016/j.scitotenv.2016.04.027

Gutiérrez-Praena D, Pichardo S, Jos Á, Cameán AM. Toxicity and glutathione implication in the effects observed by exposure of the liver fish cell line PLHC-1 to pure cylindrospermopsin. Ecotoxicol Environ Saf. 2011;74:1567-72. 
994 pathological toxic effects induced by the cyanotoxin Cylindrospermopsin on the human cell line Caco-2. Water Res. 2012; 46: 1566-75. bioaccumulation of microcystins and cylindrospermopsin in food and the effectiveness of some cooking techniques at decreasing their concentrations: A review. Food Chem. Toxicol. 2013;53:139-152. Doi: 10.1016/j.fct.2012.10.062 producing cylindrospermopsin cause oxidative stress at environmentally relevant concentrations in sub-chronically exposed tilapia (Oreochromis niloticus). Chemosphere. 2013;90:1184-94.

1004 Guzmán-Guillén R, Manzano IL, Moreno IM, Ortega AIP, Moyano R, Blanco A, 1005 Cameán AM. Cylindrospermopsin induces neurotoxicity in tilapia fish (Oreochromis 1006 niloticus) exposed to Aphanizomenon ovalisporum. Aquat Toxicol. 2015;161:17-24. Doi: 10.1016/j.aquatox.2015.01.024 Harada K, Ohtani I, Iwamoto K, Suzuki M, Watanabe MF, Watanabe M, Terao O. 1009 Isolation of cylindrospermopsin from a cyanobacterium Umezakia natans and its 1010 screening method. Toxicon. 1994;32:73-84. Doi: 10.1016/0041-0101(94)90023-X Hawkins PR, Runnegar MT, Jackson AR, Falconer IR. Severe hepatotoxicity caused by the tropical cyanobacterium (blue-green alga) Cylindrospermopsis raciborskii 1013 (Woloszynska) Seenaya and Subba Raju isolated from a domestic water supply 1014 reservoir. Appl Environ Microbiol. 1985;50:1292-5. Henry, P.F.P. Aspects of amphibian anatomy and physiology. In: Sparling, D.W., Linder, G., Bishop, C.A. (Eds.), Ecotoxicology of Am- phibians and Reptiles. 
$1018 \quad 110$.

Hu Y, Chen J, Fan H, Xie P, He J. A review of neurotoxicity of microcystins. Environ Sci Pollut Res. 2016;23:7211-9. Doi: 10.1007/s11356-016-6073-y G, Meier PJ, Stieger B. Characterization of twp splice variants of human organic anion transporting polypeptide 3A1 isolated from human brain. Am J Physiol Cell Physiol. 2007;292:795-806. Doi: 10.1152/ajpcell.00597.2005

Humpage AR, Fenech M, Thomas P, Falconer IR. Micronucleus induction and chromosome loss in transformed human white cells indicate clastogenic and aneugenic action of the cyanobacterial toxin, cylindrospermopsin. Mutat Res - Genet Toxicol Environ Mutagen. 2000;472:155-61. Humpage AR, Fontaine F, Froscio S, Burcham P, Falconer IR. Cylindrospermopsin genotoxicity and cytotoxicity: Role of cytochrome P-450 and oxidative stress. J Toxicol Environ Health - Part A. 2005;68:739-53. Doi: Johnston-Wilson NL, Sims CD, Hoffmann JP, Anderson L, Shore AD, Torrey EF, Yolken RH. Disease-specific alterations in frontal cortex brain proteins in schizophrenia, bipolar disorder, and major depressive disorder. Mol Psychiatry. 2000;5:142-149.

Jonas A, Scholz S, Fetter E, Sychrova E, Novakova K, Ortmann J, Benisek M, Adamovsky O, Giesy J, Hilscherova K. Endocrine, teratogenic and neurotoxic effects of cyanobacteria detected by cellular in vitro and zebrafish embryos assays. 
Jos A, Pichardo S, Prieto AI, Repetto G, Vázquez CM, Moreno IM, Cameán AM.

1042 Toxic cyanobacterial cells containing microcystins induce oxidative stress in exposed tilapia fish (Oreochromis sp.) under laboratory conditions. Aquat Toxicol. 2005;72:261-271. Doi: 10.1016/j.aquatox.2005.01.003

1045

Ju J, Ruan Q, Li X, Liu R, Li Y, Pu Y, Yin L, Wang D. Neurotoxicological evaluation of microcystin-LR exposure at environmental relevant concentrations on nematode Caenorhabditis elegans. Environ Sci Pollut Res. 2013;20:1823-30. Doi: $10.1007 / \mathrm{s} 11356-012-1151-2$

1049

Ju J, Saul N, Kochan C, Putschew A, Pu Y, Yin L, Steinberg CEW. Cyanobacterial 1050 xenobiotics as evaluated by a Caenorhabditis elegans neurotoxicity screening test. Int J Environ Res Public Health. 2014;11:4589-606. Doi: 10.3390/ijerph110504589

Kem WR. The brain $\alpha 7$ nicotinic receptor may be an important therapeutic target for the treatment of Alzheimer's disease: studies with DMXBA (GTS-21). Behav. Brain Res. 2000;113:169-181. Doi: 10.1016/S0166-4328(00)00211-4

1055

Kim MS, Lee YJ, Ha SY, Kim BH, Hwang SJ, Kwon JT, Choi JW, Shin KH. 1056 Accumulation of microcystin (LR, RR and YR) in three freshwater bivalves in

1057 Microcystis aeruginosa bloom using dual isotope tracer. Mar Drugs. 2017;15:1-15. Doi: $10.3390 / \mathrm{md} 15070226$ Kinnear SHW, Fabbro LD, Duivenvoorden LJ, Hibberd EMA. Multiple-organ toxicity resulting from cylindrospermopsin exposure in tadpoles of the Cane Toad (Bufo marinus). Environ Toxicol. 2007;22:550-8. Doi: 10.1002/tox.20299 isolated from a cyanobacterium, Cylindrospermopsis raciborskii, on identified 
molluscan neurones. Comp Biochem Physiol - C Toxicol Pharmacol. 2002;131:167-

Kist LW, Rosemberg DB, Pereira TCB, De Azevedo MB, Richetti SK, De Castro Leão J, Yunes JS, Bonan CD, Bogo MR. Microcystin-LR acute exposure increases AChE activity via transcriptional ache activation in zebrafish (Danio rerio) brain. Comp Biochem Physiol - C Toxicol Pharmacol. 2012;155:247-52. Doi: 10.1016/j.cbpc.2011.09.002

Li X, Liu Y, Song L, Liu J. Responses of antioxidant systems in the hepatocytes of common carp (Cyprinus carpio L.) to the toxicity of microcystin-LR. Toxicon. 2003;42:85-89. Doi: 10.1016/S0041-0101(03)00104-1 sodium chloride and diacetyl and thermotaxis defects by microcystin-LR exposure in nematode Caenorhabditis elegans. J Environ Sci. 2009a;21:971-9. Doi: 10.1016/S1001-0742(08)62370-0 as a model animal for assessing the toxicity induced by microcystin-LR. J Environ Sci. 2009b;21:395-401. investigation of chronic exposure to microcystin in relationship to childhood liver damage in the three gorges reservoir region, China. Environ Health Perspect. Li G, Chen J, Xie P, Jiang Y, Wu L, Zhang X. Protein expression profiling in the zebrafish (Danio rerio) embryos exposed to the microcystin-LR. Proteomics. 2011b;11:2003-18. Doi: 10.1002/pmic.201000442 

impairment and pathological change in rats induced by acute exposure to microcystin-LR. Environ Toxicol. 2012a;29:261-8. Doi: 10.1002/tox neurotoxicity: Implications for Alzheimer's disease. Toxicol Sci. 2012b;127:485-95. Doi: $10.1093 /$ toxsci/kfs114 Li XB, Zhang X, Ju J, Li Y, Yin L, Pu Y. Alterations in neurobehaviors and inflammation in hippocampus of rats induced by oral administration of microcystinLR. Environ Sci Pollut Res. 2014;21:12419-25. Doi: 10.1007/s11356-014-3151-x Li G, Yan W, Dang Y, Li J, Liu C, Wang J. The role of calcineurin signaling in 1098 microcystin-LR triggered neuronal toxicity. Sci Rep. 2015a;5:1-10. Doi: $10.1038 /$ srep11271

Li X, Zhang $\mathrm{X}$, Ju J, Li Y, Yin L, Pu Y. Maternal repeated oral exposure to 1101 microcystin-LR affects neurobehaviors in developing rats. Environ Toxicol Chem. 2015b;34:64-9. Doi:10.1002/etc.2765

1103

Liang G, Xie P, Chen J, Yu T. Comparative studies on the pH dependence of Dow of 1104 microcystin-RR and -LR using LC-MS. Sci. J. 2011;11:20-26.

1105

Liu W, Chen C, Chen L, Wang L, Li J, Chen Y, Jin J, Kawan A, Zhang X. Sexdependent effects of microcystin-LR on hypothalamic-pituitary-gonad axis and gametogenesis of adult zebrafish. Sci Rep. 2016;6:1-12. Doi: 10.1038/srep22819 
1110 recreational health risks in the EPA National Lakes Assessment 2007. Harmful $1111 \quad$ Algae. 2016;56:77-90. Doi: 10.1016/j.hal.2016.04.001 Lubec G, Nonaka M, Krapfenbauer K, Gratzer M, Cairns N, Fountoulakis M. Expression of the dihydropyrimidinase related protein 2 (DRP-2) in Down Syndrome and Alzheimer's disease brain is downregulated at the mRNA and dysregulated at the protein level. The molecular biology of Down syndrome. 1999. Doi: 10.1007/978-3-7091-6380-1_10 microcystin-LR is a potent and specific inhibitor of protein phosphatases 1 and $2 \mathrm{~A}$ from both mammals and higher plants. Febs. 1990;264:187-92. Doi: 10.1016/0014Maidana M, Carlis V, Galhardi FG, Yunes JS, Geracitano LA, Monserrat JM, Barros DM. Effects of microcystins over short- and long-term memory and oxidative stress generation in hippocampus of rats. Chem Biol Interact. 2006;159:223-34. Doi: Mello FD, Braidy N, Marçal H, Guillemin G, Nabavi SM, Neilan BA. Mechanisms and effects posed by neurotoxic products of cyanobacteria/microbial eukaryotes/dinoflagellates in algae blooms: a review. Neurotox Res. 2018;33:153167. Doi: 10.1007/s 12640-017-9780-3

1132 Meng G, Sun Y, Fu W, Guo Z, Xu L. Microcystin-LR induces cytoskeleton system reorganization through hyperphosphorylation of tau and HSP27 via PP2A inhibition and subsequent activation of the p38 MAPK signaling pathway in neuroendocrine (PC12) cells. Toxicology. 2011;290:219-29. Doi: 10.1016/j.tox.2011.09.085 
1134 involved in p38 activation and tau hyperphosphorylation in neuroendocrine (PC12) cells. Environ Toxicol. 2013;30:366-74. Doi: 10.1002/tox.21914 Cyanotoxin Analysis. 2017. Caenorhabditis elegans by selectively targeting the AWA sensory neuron. Toxins (Basel). 2014;6:1813-36. Doi: 10.3390/toxins6061813

Moreno IM, Mate A, Repetto G, Vázquez CM, Cameán AM. Influence of microcystin-LR on the activity of membrane enzymes in rat intestinal mucosa. $\mathrm{j}$ Physiol Biochem. 2003;59:293-9.

Mutwakil MHAZ, Reader JP, Holdich DM, Smithurst PR, Candido EPM, Jones D, Stringham EG, de Pomerai DI. Use of stress-inducible transgenic nematodes as biomarkers of heavy metal pollution in water samples from an English river system. Arch Environ Contam Toxicol. 1997;32:146-153.

Nadal E, Ammerer G, Posas F. Controlling gene expression in response to stress. Nat Rev Genet. 2011;12:833-845. Doi: 10.1038/nrg3055 Distribution of ${ }^{14} \mathrm{C}$ cylindrospermopsin in vivo in the mouse. Environ. Toxicol. $1152 \quad 2001 ; 16: 1-8$.

Ohtani I, Moore RE, Runnegar MTC. Cylindrospermopsin: a potent hepatotoxin from the blue-green algae Cylindrospermopsis raciborskii. J Am Chem Soc. 1992;114:7941-2. 

myoglobin and neuroglobin in goldfish (Carassius auratus) exposed to MC-RR under varying oxygen level. Chemosphere. 2014;112:427-34. Doi: Seasonal variation of the three native gonadotropin-releasing hormone messenger ribonucleic acids levels in the brain of female red seabream. Gen. Comp. Endocrinol. 2003;130:324-32. Doi: 10.1016/S0016-6480(02)00629-9 Babica P, Maršálek B, Hilscherová K. Detoxification and oxidative stress responses along with microcystins accumulation in Japanese quail exposed to cyanobacterial biomass. Sci Total Environ. 2008;398:34-47. Doi: 10.1016/j.scitotenv.2008.03.001 R. Biochemical response of diverse organs in adult Danio rerio (zebrafish) exposed to sub-lethal concentrations of microcystin-LR and microcystin-RR: A balneation study. Aquat Toxicol. 2012;109:1-10. Doi: 10.1016/j.aquatox.2011.11.009 potential threat to human health in Europe. Environ Toxicol Pharmacol. Pouria S, De Andrade A, Barbosa J, Cavalcanti RL, Barreto VTS, Ward CJ, Preiser W, Poon GK, Neild GH, Codd GA. Fatal microcystin intoxication in haemodialysis unit in Caruaru, Brazil. Lancet. 1998;352:21-6. Doi: 10.1016/S0140-6736(97)12285- 
Preece EP, Moore BC, Hardy FJ. Transfer of microcystin from freshwater lakes to

1180 Puget Sound, WA and toxin accumulation in marine mussels (Mytilus trossulus). Ecotoxicol Environ Saf. 2015;122:98-105. Doi: 10.1016/j.ecoenv.2015.07.013 Prieto AI, Jos A, Pichardo S, Moreno I, Cameán AM. Protective role of vitamin E on the microcystin-induced oxidative stress in tilapia fish (Oreochromis niloticus). Environ Toxicol Chem. 2009;27:1152-1159. Doi: 10.1897/tox.2045807-496.1 Puerto M, Gutiérrez-Praena D, Prieto AI, Pichardo S, Jos A, Miguel-Carrasco JL, Vázquez CM, Cameán AM. Subchronic effects of cyanobacterial cells on the transcription of antioxidant enzyme genes in tilapia (Oreochromis niloticus). Ecotoxicology. 2011;20:479-90. Doi: 10.1007/s10646-011-0600-x Cameán AM. Mutagenic and genotoxic potential of pure Cylindrospermopsin by a battery of in vitro tests. Food Chem Toxicol. 2018;121:413-22.

Qian H, Liu G, Lu T, Sun L. Developmental neurotoxicity of Microcystis aeruginosa 1193 in the early life stages of zebrafish. Ecotoxicol Environ Saf. 2018;151:35-41. Doi: 10.1016/j.ecoenv.2017.12.059 microcystin on cardiac antioxidant enzymes, mitochondrial function and cardiac toxicity in rat. Toxicology. 2009;257:86-94. Doi: 10.1016/j.tox.2008.12.01 cyanobacteria and their implications on human health. J Environ Biol. 2002;23:215224. 
Rinehart KL, Namikoshi M, Choi BW. Structure and biosynthesis of toxins from

1202

1203

1204

1205

1206

1207

1208

1209

1210

1211

1212

1213

1214

1215

1216

1217

1218

1219

1220

1221

1222

1223

blue-green algae (cyanobacteria). J Appl Phycol. 1994;6:159-176. Doi: 10.1007/BF02186070.

Romero-Oliva CS, Contardo-Jara V, Block T, Pflugmacher S. Accumulation of microcystin congeners in different aquatic plants and crops - A case study from lake Amatitlán, Guatemala. Ecotoxicol Environ Saf. 2014;102:121-8. Doi: 10.1016/j.ecoenv.2014.01.031

Roos WP, Kaina B. DNA damage-induced cell death by apoptosis. Trends Mol Med. 2006;12:440-50.

Roy-Lachapelle A, Solliec M, Sinotte M, Deblois C, Sauvé S. total analysis of microcystins in fish tissue using laser thermal desorption-atmospheric pressure chemical ionization-high-resolution mass spectrometry (LDTD-APCI-HRMS). J Agric Food Chem. 2015;63:7440-49. Doi: 10.1021/acs.jafc.5b02318

Rozman KB, Jurič DM, Šuput D. Selective cytotoxicity of microcystins LR, LW and LF in rat astrocytes. Toxicol Lett. 2017;265:1-8. Doi: 10.1016/j.toxlet.2016.11.008

Runnegar MT, Kong S-M, Zhong Y-Z, Lu SC. Inhibition of reduced glutathione synthesis by cyanobacterial alkaloid cylindrospermopsin in cultured rat hepatocytes. Biochem Pharmacol. 1995;49:219-25.

Saker ML, Eaglesham GK. The accumulation of cylindrospermopsin from the cyanobacterium Cylindrospermopsis raciborskii in tissues of the redclaw crayfish Cherax quadricarinatus. Toxicon. 1999;37:1065-77. Doi: 10.1016/S00410101(98)00240-2

Saker ML, Nogueira ICG, Vasconcelos VM, Neilan BA, Eaglesham GK, Pereira, P. 

250. action of microcystin-LR is reflected in the transcriptional stress response of Caenorhabditis elegans. Chem Biol Interact. 2014;223:51-7. Doi: 10.1016/j.cbi.2014.09.007 of thermosensory neuron fate in $C$. elegans requires ttx-1, a homolog of otd/Otx. Neuron. 2001;31:943-956.

Schembri MA, Neilan BA, Saint CP. Identification of genes implicated in toxin 1235 production in the cyanobacterium Cylindrospermopsis raciborskii. Environ Toxicol. $1236 \quad 2001 ; 16: 413-21$.

Schoeb TR, Heaton-Jones TG, Clemmons RM, Carbonneau DA, Woodward AR, Shelton D, Poppenga RH. Clinical and Necropsy Findings Associated With Increased Mortality Among American Alligators of Lake Griffin, Florida. J Wildl Dis. 2002;38:320-37. Doi: 10.7589/0090-3558-38.2.320

Shaw GR, Sukenik A, Livne A, Chiswell RK, Smith MJ, Seawright AA, Norris RL, Eaglesham GK, Moore MR. Blooms of the cylindrospermopsin containing

1244 Queensland, Australia. Environ Toxicol. 1999;14:167-77.

1245 Shaw GR, Seawright AA, Moore MR, Lam PK. Cylindrospermopsin, a 1246 cyanobacterial alkaloid: evaluation of its toxicologic activity. Ther Drug Monit. 2000;22:89-92. 
HC. Glutathione peroxidase-1 overexpressing transgenic mice are protected from neurotoxicity induced by microcystin-leucine-arginine. Environ Toxicol.

Simiyu BM, Oduor SO, Rohrlack T, Sitoki L, Kurmayer R. microcystin content in phytoplankton and in small fish from eutrophic Nyanza Gulf, Lake Victoria, Kenya. Toxins. 2018;10:1-19. Doi: 10.3390/toxins10070275

Sivonen K, Jones G. Cyanobacterial toxins. In: Chorus, I. and Bartram, J., Eds., Toxic cyanobacteria in water: a guide to their public health consequences, monitoring, and management, E \& FN Spon. 1999:41-111.

Skocovska B, Hilscherova K, Babica P, Adamovsky O, Bandouchova H, Horakova J, Knotkova Z, Marsalek B, Paskova V, Pikula J. Effects of cyanobacterial biomass on the Japanese quail. Toxicon. 2007;49:793-803. Doi: 10.1016/j.toxicon.2006.11.032

Song W, de la Cruz AA, Rein K, O'Shea KE. Ultrasonically induced degradation of $10.1021 / \mathrm{es} 0521730$

Spoof L, Catherine A. Appendix 3, in: Meriluto J, Spoof L, Codd GA. Handbook of cyanobacterial monitoring and cyanotoxin analysis. 2017;526-537. stress research. Prog Neuropsychopharmacol Biol Psychiatry. 2011;35:1432-1451. Doi: 10.1016/j.pnpbp.2010.10.010 
Stillwell W. Chapter 14 - Membrane transport, in: An introduction to biological 1271 membranes: from bilayers to rafts. 2013;305-337. interferes with the reproductive endocrine system of male zebrafish. Aquat. Toxicol. 2016;175:205-212. Doi: 10.1016/j.aquatox.2016.03.018 apoptosis and inflammatory effects in murine brain cells: Potential implications for neurodegenerative diseases. Toxicol Reports. 2016;3:180-9. Doi: 10.1016/j.toxrep.2015.12.008 Terao K, Ohmori S, Igarashi K, Ohtani I, Watanabe MF, Harada KI, Ito E, Watanabe E. Electron microscopic studies on experimental poisoning in mice induced by cylindrospermopsin isolated from blue-green alga Umezakia natans. Toxicon. Testai E, Buratti FM, Funari E, Manganelli M, Vichi S, Arnich N, Biré R, Fessard V, Doi: $10.3390 /$ toxins 7041206 protein phosphatase 1 and $2 \mathrm{~A}$ inhibitory activity of naturally occurring desmethylmicrocystins and nodularins. Toxicology 2012;293:59-67 
Vehovszky A, Kovács AW, Farkas A, Györi J, Szabó H, Vasas G. Pharmacological studies confirm neurotoxic metabolite(s) produced by the bloom-forming Cylindrospermopsis raciborskii in Hungary. Environ Toxicol. 2013;30:501-12. Doi: 10.1002/tox.21927

Vesterkvist PSM, Meriluoto JAO. Interaction between microcystins of different hydrophobicities and lipid monolayers. Toxicon. 2003;41:349-55. Doi: $10.1016 / \mathrm{S} 0041-0101(02) 00315-\mathrm{X}$

Vichi S, Testai E, Buratti F. Marine and freshwater toxins. J AOAC Int. 2016;89:248-69.

Wang Q, Xie P, Chen J, Liang G. Distribution of microcystins in various organs (heart, liver, intestine, gonad, brain, kidney and lung) of Wistar rat via intravenous injection. Toxicon. 2008;52:721-7. Doi: 10.1016/j.toxicon.2008.08.004 Wang M, Wang D, Lin L, Hong H. Protein profiles in zebrafish (Danio rerio) brains exposed to chronic microcystin-LR. Chemosphere. 2010;81:716-24. Doi: 10.1016/j.chemosphere.2010.07.061

Wang X, Ying F, Chen Y, Han X. Microcystin (-LR) affects hormones level of male 1309 mice by damaging hypothalamic-pituitary system. Toxicon. 2012;59:205-14. Doi: 10.1016/j.toxicon.2011.12.001

Wang J, Lin F, Cai F, Yan W, Zhou Q, Xie L. Microcystin-LR inhibited hippocampal long-term potential via regulation of the glycogen synthase kinase- $3 \beta$ pathway. Chemosphere. 2013;93:223-9. Doi: 10.1016/j.chemosphere.2013.04.069 
Wang X, Xu L, Li X, Chen J, Zhou W, Sun J, Wang Y. The differential effects of microcystin-LR on mitochondrial DNA in the hippocampus and cerebral cortex. Environ Pollut. 2018;240:68-76. Doi: 10.1016/j.envpol.2018.04.103 Ward CJ, Codd GA. Comparative toxicity of four microcystins of different hydrophobicities to the protozoan, Tetrahymena pyriformis. J Appl Microbiol. 1999;86:874-882. Doi: 10.1046/j.1365-2672.1999.00771.x

Weng D, Lu Y, Wei Y, Liu Y, Shen P. The role of ROS in microcystin-LR-induced hepatocyte apoptosis and liver injury in mice. Toxicol. 2007;232:15-23. Doi: 10.1016/j.tox.2006.12.010

Westholm DE, Salo DR, Viken KJ, Rumbley JN, Anderson GW. The blood-brain barrier thyroxine transporter organic anion-transporting polypeptide 1c1 displays atypical transport kinetics. Endocrinology. 2009;150:5153-5162. Doi: 10.1210/en.2009-0769

White JG, Southgate E, Thomson JN, Brenner S. The structure of the nervous system of the nematode Caenorhabditis elegans. Phil Tras R Soc Lond. 1986;314:1-340.

White SH, Duivenvoorden LJ, Fabbro LD, Eaglesham GK. Mortality and toxin bioaccumulation in Bufo marinus following exposure to Cylindrospermopsis raciborskii cell extracts and live cultures. Environ Pollut. 2007;147:158-67.

Wu Q, Yan W, Liu C, Li L, Yu L, Zhao S, Li G. Microcystin-LR exposure induces developmental neurotoxicity in zebrafish embryo. Environ Pollut. 2016;213:793-800. Doi: 10.1016/j.envpol.2016.03.048 
Wu Q, Cheng H, Liu C, Hung TC, Guo X, Li G. Parental transfer of microcystin-LR induced transgenerational effects of developmental neurotoxicity in zebrafish offspring. Environ Pollut. 2017;231:471-478. Doi: 10.1016/j.envpol.2017.08.038

Xie L, Yokoyama A, Nakamura K, Park H. Accumulation of microcystins in various organs of the freshwater snail Sinotaia histrica and three fishes in a temperate lake, microcystin-LR alters thyroid hormone levels and gene transcription in the hypothalamic-pituitary-thyroid axis in zebrafish larvae. Chemosphere. 2012;87:1301-7. Doi: 10.1016/j.chemosphere.2012.01.041 neurotransmitter system of zebrafish. Aquat Toxicol. 2017;188:170-6. Doi: 10.1016/j.aquatox.2017.05.006 WW, Fujiki H. Inhibition of protein phosphatases by microcystis and nodulatin associated with hepatotoxicity. J Cancer Res Clin Oncol. 1990;116:609-614. 
1358 Žegura B, Štraser A, Filipič M. Genotoxicity and potential carcinogenicity of 1359 cyanobacterial toxins - a review. Mutat Res - Rev Mutat Res. 2011;727:16-41. Doi:

$1360 \quad$ 10.1016/j.mrrev.2011.01.002

1361 Zeng C, Sun H, Xie P, Wang J, Zhang G, Chen N, Yan W, Li G. The role of 1362 apoptosis in MCLR-induced developmental toxicity in zebrafish embryos. Aquat 1363 Toxicol. 2014;149:25-32. Doi: 10.1016/j.aquatox.2014.01.02

1364 Zhang Y, Zhang J, Wang E, Qian W, Fan Y, Feng Y, Yin H, Li H, Wang Y, Yuan T. 1365 Microcystin-leucine-arginine induces tau pathology through $\mathrm{B} \alpha$ degradation via 1366 protein phosphatase $2 \mathrm{a}$ demethylation and associated glycogen synthase kinase-3 $\beta$ 1367 phosphorylation. Toxicol Sci. 2018;162:475-87. Doi: 10.1093/toxsci/kfx271

1368 Zhao S, Li G, Chen J. A proteomic analysis of prenatal transfer of microcystin-LR 1369 induced neurotoxicity in rat offspring. J Proteomics. 2015a;114:197-213. Doi: $1370 \quad 10.1016 / j . j p r o t .2014 .11 .015$

1371 Zhao Y, Xie L, Yan Y. Microcystin-LR impairs zebrafish reproduction by affecting 1372 oogenesis and endocrine system. Chemosphere. 2015b;120:115-122. Doi: 
Table 1.

\begin{tabular}{|c|c|c|c|c|c|c|c|}
\hline \multirow[b]{2}{*}{ Toxin } & \multirow[b]{2}{*}{ Chemical structure } & \multicolumn{4}{|c|}{ Molecular properties } & \multicolumn{2}{|c|}{ Environmental concentrations } \\
\hline & & $\begin{array}{c}\text { Molecular } \\
\text { weight } \\
{[\mathrm{M}+\mathrm{H}]^{+}}\end{array}$ & $\begin{array}{c}\text { Molecular } \\
\text { composition }\end{array}$ & Kow & $\begin{array}{c}\text { BCF } \\
\text { Plants }\end{array}$ & $\begin{array}{c}\text { In surface waters } \\
(\mu \mathrm{g} / \mathrm{L})\end{array}$ & $\begin{array}{c}\text { In mollusks and fish } \\
\text { samples } \\
(\text { ng/g d.w })\end{array}$ \\
\hline MC-LR & $\begin{array}{l}\text { Cyclo(-D-Ala-L-Leu-D-erythro- } \beta \text { - } \\
\text { methylAsp(iso-linkage)-L-Arg-Adda-D- } \\
\text { Glu(iso-linkage)- } N \text {-methyldehydro-Ala }\end{array}$ & 995.5561 & $\mathrm{C}_{49} \mathrm{H}_{75} \mathrm{~N}_{10} \mathrm{O}_{12}$ & $\begin{array}{c}2.16 \\
\text { (Ward and } \\
\text { Codd, 1999) }\end{array}$ & $\begin{array}{c}\text { Up to } \\
680.05 \pm 40.88 \\
\text { (Romero-Oliva et } \\
\text { al., 2014) }\end{array}$ & $\begin{array}{l}\text { Up to } 2100 \\
\text { (Faasen and } \\
\text { Lurling 2013) }\end{array}$ & $\begin{array}{l}\text { Up to } 130 \text { in fish muscle } \\
\text { (Roy-Lachapelle et al., } \\
\text { 2015) }\end{array}$ \\
\hline MC-LF & $\begin{array}{l}\text { Cyclo(-D-Ala-L- Leu -D-erythro- } \beta \text { - } \\
\text { methylAsp(iso-linkage)-L-Fe-Adda-D- } \\
\text { Glu(iso-linkage)- } N \text {-methyldehydro-Ala }\end{array}$ & 986.5234 & $\mathrm{C}_{52} \mathrm{H}_{72} \mathrm{~N}_{7} \mathrm{O}_{12}$ & $\begin{array}{c}3.56 \\
\text { (Ward and } \\
\text { Codd, 1999) } \\
\end{array}$ & $\mathrm{nf}$ & $\begin{array}{c}\text { Up to } 51 \\
\text { (Graham et al., } \\
\text { 2010) }\end{array}$ & $\begin{array}{l}\text { Up to } 300 \text { in common carp } \\
\text { (Gurbuz et al., 2016) }\end{array}$ \\
\hline MC-LW & $\begin{array}{l}\text { Cyclo(-D-Ala-L- Leu -D-erythro- } \beta \text { - } \\
\text { methylAsp(iso-linkage)-L-Trp-Adda-D- } \\
\text { Glu(iso-linkage)- } N \text {-methyldehydro-Ala }\end{array}$ & 1025.5343 & $\mathrm{C}_{54} \mathrm{H}_{73} \mathrm{~N}_{8} \mathrm{O}_{12}$ & $\begin{array}{c}3.46 \\
\text { (Ward and } \\
\text { Codd, 1999) }\end{array}$ & $\mathrm{nf}$ & $\begin{array}{c}\text { Up to 260 } \\
\text { (Faasen and } \\
\text { Lurling 2013) }\end{array}$ & $\begin{array}{l}\text { Up to } 15.5 \text { in bivalves } \\
\text { (Preece et al., 2015) }\end{array}$ \\
\hline MC-RR & $\begin{array}{l}\text { Cyclo(-D-Ala-L- Arg -D-erythro- } \beta \text { - } \\
\text { methylAsp(iso-linkage)-L- Arg -Adda-D- } \\
\text { Glu(iso-linkage)- } N \text {-methyldehydro-Ala }\end{array}$ & 1038.5731 & $\mathrm{C}_{49} \mathrm{H}_{76} \mathrm{~N}_{13} \mathrm{O}_{12}$ & $\begin{array}{l}1.54 \\
\text { (Liang et al., } \\
\text { 2011) }\end{array}$ & $\begin{array}{c}\text { Up to } \\
54.09 \pm 17.01 \\
\text { (Romero-Oliva et } \\
\text { al., 2014) } \\
\end{array}$ & $\begin{array}{l}\text { Up to } 16000 \\
\text { (Graham et al., } \\
\text { 2010) }\end{array}$ & $\begin{array}{l}\text { Up to } 463000 \text { in silver } \\
\text { carp } \\
\text { (Xie et al., 2007) }\end{array}$ \\
\hline MC-YR & $\begin{array}{l}\text { Cyclo(-D-Ala-L-Tir-D-erythro- } \beta \text { - } \\
\text { methylAsp(iso-linkage)-L- Arg -Adda-D- } \\
\text { Glu(iso-linkage)- } N \text {-methyldehydro-Ala }\end{array}$ & 1045.5353 & $\mathrm{C}_{52} \mathrm{H}_{73} \mathrm{~N}_{10} \mathrm{O}_{13}$ & $\mathrm{nf}$ & $\mathrm{nf}$ & $\begin{array}{l}\text { Up to } 343 \\
\text { (Simiyu et al., } \\
2018 \text { ) }\end{array}$ & $\begin{array}{l}\text { Up to } 20000 \text { in bivalves } \\
\text { (Kim et al., 2017) }\end{array}$ \\
\hline CYN & $\begin{array}{c}\text { 2,4(1H,3H)-Pyrimidinedione, 6-[(R)- } \\
\text { hydroxy[2a } R, 3 S, 4 R, 5 \mathrm{a} R, 7 S) \text { - } \\
\text { 2,2a,3,4,5,5a,6,7-octahydro-3-methyl-4- } \\
\text { (sulfooxy)- } 1 H \text {-1,8,8b-triazaacenaphthylen- } \\
\text { 7-yl]methyl]-, rel-(-)- (9CI) }\end{array}$ & 416.1234 & $\mathrm{C}_{15} \mathrm{H}_{21} \mathrm{~N}_{5} \mathrm{O}_{7} \mathrm{~S}$ & $\begin{array}{l}\text { Highly water- } \\
\text { soluble }\end{array}$ & $\begin{array}{l}\text { Up to } 3.88 \pm 0.33 \\
\text { (Cordeiro-Araújo } \\
\text { et al., 2017) }\end{array}$ & $\begin{array}{l}\text { Up to } 800 \\
\text { (Shaw et al., } \\
\text { 2000) }\end{array}$ & $\begin{array}{l}\text { Up to } 200 \text { in crayfish } \\
\text { (Saker ans Eaglesham, } \\
\text { 1999) }\end{array}$ \\
\hline
\end{tabular}

Abbreviations: BCF: bioconcentration factor; d.w: dry weight; Kow : octanol/water partition coefficients; nf: not found; 
Table 2.

\begin{tabular}{|c|c|c|c|c|c|c|}
\hline Toxin & $\begin{array}{c}\text { Experimental } \\
\text { model }\end{array}$ & $\begin{array}{c}\text { Experimental } \\
\text { conditions }\end{array}$ & Assays Performed & Relevant results & $\mathbf{L C}_{50}$ & References \\
\hline $\begin{array}{l}\text { Pure MC-LR } \\
\text { Pure MC-LW } \\
\text { Pure MC-LF }\end{array}$ & $\begin{array}{l}\text { Primary } \\
\text { murine WBC }\end{array}$ & $\begin{array}{l}0,0.2,0.4,0.6 \\
0.8,1,3 \text { and } 5 \\
\mu \mathrm{M} \text { for } 48 \text { hours }\end{array}$ & $\begin{array}{l}\text { MTT assay } \\
\text { PPI assay }\end{array}$ & $\begin{array}{l}\text { At } 5 \mu \mathrm{M} \text {, complete loss of cell viability by MC-LF, decrease of } \\
\text { cell viability by MC-LR and MC-LW ( } 54 \% \text { and } 33 \% \text {, } \\
\text { respectively). } \\
\text { Decrease of cell viability after exposure to -LF, -LW and -LR } \\
\text { to } \geq 200 \mathrm{nM}, \geq 400 \mathrm{nM} \text { and } \geq 600 \mathrm{nM} \text {, respectively. }\end{array}$ & $\begin{array}{l}>10 \mu \mathrm{M} \\
3 \mu \mathrm{M} \text { aprox } \\
3 \mu \mathrm{M} \text { aprox }\end{array}$ & $\begin{array}{l}\text { Feurstein } \\
\text { et al. } \\
(2009)\end{array}$ \\
\hline $\begin{array}{l}\text { Pure MC-LR } \\
\text { Pure MC-LW } \\
\text { Pure MC-LF }\end{array}$ & $\begin{array}{l}\text { Primary } \\
\text { murine } \\
\text { neurons }\end{array}$ & $\begin{array}{l}0,0.31,0.63 \\
1.25,2.5, \text { and } 5 \\
\mu \mathrm{M} \text { for } 48 \text { hours }\end{array}$ & PPI assay & $\begin{array}{l}20 \% \text { inhibition of PP activity at low MCs concentrations. } \\
\text { Decrease of activity at } 2.5 \mu \mathrm{M} \text { by } 25 \% \text { (-LR), } 30 \% \text { (-LW), and } \\
60 \% \text { (-LF). } \\
\text { Decrease of PP activity by } 65 \% \text { at } 5 \mu \mathrm{M} \text {-LF. }\end{array}$ & - & $\begin{array}{l}\text { Feurstein } \\
\text { et al. } \\
(2010)\end{array}$ \\
\hline $\begin{array}{l}\text { Pure MC-LR } \\
\text { Pure MC-LW } \\
\text { Pure MC-LF }\end{array}$ & $\begin{array}{l}\text { Primary } \\
\text { murine CGNs }\end{array}$ & $\begin{array}{l}0,0.2,0.4,0.5, \\
0.6,0.8,1,3,5 \\
\text { and } 10 \mu \mathrm{M} \text { for } \\
48 \text { hours }\end{array}$ & $\begin{array}{l}\text { MTT assay } \\
\text { Apoptosis } \\
\text { Morphology } \\
\text { PPI assay } \\
\text { Tau phosphorylation }\end{array}$ & $\begin{array}{l}\text { At } 5 \mu \mathrm{M} \text {, decrease of cell viability by -LR (to } 70 \% \text { ), -LW (to } \\
50 \% \text { ) and -LF (to } 8 \% \text { ). } \\
3-5 \mu \mathrm{M} \text {-LF caused the highest level of apoptosis. Apoptotic } \\
\text { nuclei at } 5 \mu \mathrm{M} \text {-LW while -LR did not induced them at any } \\
\text { concentration assayed. } \\
\text { Enhance of caspase-3/7 activity for -LF and -LW, and no } \\
\text { changes for -LR. } \\
\text {-LF caused a complete disintegration of the neurite network, } \\
\text { whereas -LR induced a slight impairment. } \\
\text { No statistical differences in PPI of -LR, while -LF induced a } \\
\text { concentration-dependent inhibition from } 2.5 \mu \mathrm{M} \text {. } \\
\text { Tau phosphorylation fast and potent for -LF, being less evident } \\
\text { for -LW, and with a low constant signal for -LR. }\end{array}$ & $\begin{array}{l}>10 \mu \mathrm{M} \\
5 \mu \mathrm{M} \\
1.5 \mu \mathrm{M} \text { aprox }\end{array}$ & $\begin{array}{l}\text { Feurstein } \\
\text { et al. } \\
(2011)\end{array}$ \\
\hline Pure MC-LR & $\begin{array}{l}\text { Differentiated } \\
\text { PC12 cells }\end{array}$ & $\begin{array}{l}0,0.1,0.5,1,5 \\
\text { and } 10 \mu \mathrm{M} \text { for } 6 \\
\text { hours }\end{array}$ & $\begin{array}{l}\text { PPI assay } \\
\text { Tau phosphorylation } \\
\text { p38-MAPK activation } \\
\text { Morphology }\end{array}$ & $\begin{array}{l}\text { MC-LR caused a concentration-dependent significant inhibition } \\
\text { of PP2A by } 27.4 \% \text { at low concentrations, by } 36.5 \% \text { at } 5 \mu \mathrm{M} \\
\text { and by } 60.5 \% \text { at } 10 \mu \mathrm{M} \text {, leading to Tau hyperphosphorylation. } \\
\text { Drastic enhance of p38-MAPK phosphorylation with } 10 \mu \mathrm{M} \\
\text { MC-LR. } \\
\text { Loss of the regular filamentous distribution and decrease of } \\
\text { tubulin and actin fibers in the cytosol, enhancing in the } \\
\text { periphery. }\end{array}$ & - & $\begin{array}{l}\text { Meng et al. } \\
(2011)\end{array}$ \\
\hline Pure MC-LR & $\begin{array}{l}\text { Differentiated } \\
\text { PC12 cells }\end{array}$ & $\begin{array}{l}0,1,2.5,5,7.5 \\
\text { and } 10 \mu \mathrm{M} \text { for }\end{array}$ & $\begin{array}{l}\text { ROS } \\
\text { Tau phosphorylation }\end{array}$ & $\begin{array}{l}\text { MC-LR induced a concentration- and time-dependent alteration } \\
\text { of intracellular ROS until } 6 \text { hours of exposure, recovering to the }\end{array}$ & - & $\begin{array}{l}\text { Meng et al. } \\
(2013)\end{array}$ \\
\hline
\end{tabular}




\begin{tabular}{|c|c|c|c|c|c|c|}
\hline & & 24 hours & p38-MAPK activation & $\begin{array}{l}\text { baseline at } 18 \text { hours. A Tau phosphorylation was observed from } \\
1 \text { hour of exposure, reaching the highest effect at } 3 \text { hours, and } \\
\text { gradually decreasing to basal levels. } \\
\text { Enhance of p38-MAPK activation from } 1 \text { to } 24 \text { hours of } \\
\text { exposure. }\end{array}$ & & \\
\hline Pure MC-LR & $\begin{array}{l}\text { Primary } \\
\text { hippocampal } \\
\text { neurons }\end{array}$ & $\begin{array}{l}0,0.1,0.3,1,3, \\
10 \text { and } 30 \mu \mathrm{M} \\
\text { for } 24 \text { hours }\end{array}$ & $\begin{array}{l}\text { MTT assay } \\
\text { Calcium mobilization }\end{array}$ & $\begin{array}{l}\text { Decrease of cell viability by MC-LR in a concentration- } \\
\text { dependent way. } \\
\text { Enhance of apoptotic and necrotic neurons number with } 1 \mu \mathrm{M} \\
\text { MC-LR. The toxin induced a concentration-dependent } \\
\text { intracellular calcium mobilization. }\end{array}$ & $10 \mu \mathrm{M}$ aprox & $\begin{array}{l}\text { Cai et al. } \\
(2015)\end{array}$ \\
\hline Pure MC-LR & $\begin{array}{l}\text { Primary } \\
\text { hippocampal } \\
\text { neurons }\end{array}$ & $\begin{array}{l}0,0.3 \text { and } 3 \mu \mathrm{M} \\
\text { for } 48 \text { hours }\end{array}$ & $\begin{array}{l}\text { Proteome analysis } \\
\text { CaN activity } \\
\text { MTT assay } \\
\text { LDH release }\end{array}$ & $\begin{array}{l}\text { Alteration of } 45 \text { proteins implied in calcium-ion signal } \\
\text { transduction, apoptosis, oxidative stress response, and } \\
\text { cytoskeleton structure. } \\
\text { Enhance of CaN levels. } \\
\text { Decrease of cell viability at the highest MC-LR concentration } \\
\text { assayed. } \\
\text { Enhance of LDH release with the increment of the } \\
\text { concentration. }\end{array}$ & - & $\begin{array}{l}\text { Li et al. } \\
(2015 a)\end{array}$ \\
\hline Pure MC-LR & $\begin{array}{l}\text { BV-2 cells } \\
\text { N2a cells }\end{array}$ & $\begin{array}{l}0,0.1 \text { and } 10 \\
\mu \mathrm{M} \text { for } 24,48 \\
\text { and } 72 \text { hours }\end{array}$ & MTT assay & $\begin{array}{l}\text { BV-2 cells exposed to MC-LR never reached LD } \text { L }_{50} \text { levels at any } \\
\text { of the exposure times, but significant decrease of viability after } \\
24 \text { hours at both MC-LR concentrations, and only at } 10 \mu \mathrm{M} \\
\text { after } 48 \text { and } 72 \text { hours. } \\
\text { Decrease of cell viability after exposure to both concentrations } \\
\text { assayed after } 24,48 \text { and } 72 \text { hours in N2a cells. }\end{array}$ & $\begin{array}{l}>10 \mu \mathrm{M} \\
10 \mu \mathrm{M} \text { aprox }\end{array}$ & $\begin{array}{l}\text { Takser et } \\
\text { al. }(2016)\end{array}$ \\
\hline Pure MC-LR & GT1-7 cells & $\begin{array}{l}0,0.01,0.05 \\
0.1,0.5 \text { and } 1 \\
\mu \mathrm{M} \text { for } 48 \text { hours }\end{array}$ & $\begin{array}{l}\text { Toxin uptake } \\
\text { CCK-8 test }\end{array}$ & $\begin{array}{l}\text { Uptake of MC-LR into cells was confirmed by western-blot, } \\
\text { since it covalently bound to the PP1 and PP2A catalytic } \\
\text { subunits. } \\
\text { Decrease of cell viability in a concentration-dependent way. No } \\
\text { affectation when deprived from the Oatp1a5 transporter. }\end{array}$ & - & $\begin{array}{l}\text { Ding et al. } \\
(2017)\end{array}$ \\
\hline $\begin{array}{l}\text { Pure MC-LR } \\
\text { Pure MC-LW } \\
\text { Pure MC-LF }\end{array}$ & $\begin{array}{l}\text { Primary rat } \\
\text { astrocytes }\end{array}$ & $\begin{array}{l}0,0.5,2 \text { and } 10 \\
\mu \mathrm{M} \text { for } 24 \text { hours }\end{array}$ & $\begin{array}{l}\text { MTT assay } \\
\text { Apoptosis } \\
\text { Immunocytochemistry } \\
\text { Morphology }\end{array}$ & $\begin{array}{l}\text { Intracellular localization of MCs using immunocytochemistry. } \\
\text { Cytoskeletal disruption, decrease of cell viability and enhance } \\
\text { of number of apoptotic cells after MC-LW and MC-LF } \\
\text { exposure. } \\
\text { MC-LR did not cause any of the alterations above. }\end{array}$ & - & $\begin{array}{l}\text { Rozman et } \\
\text { al. (2017) }\end{array}$ \\
\hline Pure MC-LR & $\begin{array}{l}\text { SH-SY5Y } \\
\text { cells }\end{array}$ & $\begin{array}{l}0,5 \text { and } 10 \mu \mathrm{M} \\
\text { for } 24 \text { hours }\end{array}$ & $\begin{array}{l}\text { Toxin uptake } \\
\text { Tau phosphorylation }\end{array}$ & $\begin{array}{l}\text { Uptake of MC-LR into cells confirmed by western-blot, using } \\
\text { PP1 and PP2A catalytic subunits-antibodies. }\end{array}$ & - & $\begin{array}{l}\text { Zhang et } \\
\text { al. (2018) }\end{array}$ \\
\hline
\end{tabular}




\begin{tabular}{|l|l|l|l|l|}
\hline & & $\begin{array}{l}\text { PPI assay } \\
\text { LDH release }\end{array}$ & $\begin{array}{l}\text { Enhance of Tau phosphorylation the concentration of } \\
\text { accumulated MC-LR. } \\
\text { The PP2A activity was inhibited in a concentration-dependent } \\
\text { way. } \\
\text { The highest MC-LR concentration caused cell dead, related to } \\
\text { Tau phosphorylation. }\end{array}$ & \\
& & & \\
\hline
\end{tabular}

Abbreviations: BV-2: cellosaurus cell line; CaN: calcineurin; CCK-8: cell counting kit-8 test; CGNs: cerebellar granule neurons; GT1-7: hypothalamic neuronal mouse cells 17); LDH: lactate dehydrogenase; MTT: 3-(4,5-dimethylthiazol-2-yl)-2,5-diphenyltetrazolium bromide; N2a: fast-growing mouse neuroblastoma cells; Oatp: organic-aniontransporting-polypeptide; p38-MAPK: P38 mitogen-activated protein kinases; PC12: pheochromocytoma of rat adrenal medulla; PP: protein phosphatase; PPI assay: protein phosphatase inhibition assay; ROS: reactive oxygen species; SH-SY5Y: Homo sapiens bone marrow neuroblast; WBC: whole brain cells. 
Table 3.

\begin{tabular}{|c|c|c|c|c|c|}
\hline $\begin{array}{c}\text { Microcystin } \\
\text { congener/Cyanobacteria }\end{array}$ & $\begin{array}{l}\text { Experimental } \\
\text { model }\end{array}$ & Experimental conditions & Assays performed & Relevant Results & References \\
\hline \multicolumn{6}{|c|}{ Aquatic animals } \\
\hline Pure MC-LR & $\begin{array}{l}\text { Zebrafish } \\
\text { (Danio rerio) }\end{array}$ & $\begin{array}{l}0.5,5 \text { or } 15 \mu \mathrm{g} / \mathrm{L} \text { for } 25 \text { days } \\
\text { and } 50 \mu \mathrm{g} / \mathrm{L} \text { for } 6 \text { days, by } \\
\text { oral and transdermal route }\end{array}$ & Behavioral study & $\begin{array}{l}\text { The motility showed a dose-effect } \\
\text { relationship and changes in the } \\
\text { circadian rhythm }\end{array}$ & $\begin{array}{l}\text { Baganz et al. } \\
\text { (1998) }\end{array}$ \\
\hline \multirow[t]{2}{*}{ Pure MC-LR } & $\begin{array}{l}\text { Zebrafish } \\
\text { (Danio rerio) }\end{array}$ & \multirow{2}{*}{$\begin{array}{l}0.5,5 \text { or } 15 \mu \mathrm{g} / \mathrm{L} \text { for } 17 \text { days } \\
\text { and } 50 \mu \mathrm{g} / \mathrm{L} \text { for } 6 \text { days, by } \\
\text { oral and transdermal route }\end{array}$} & \multirow[t]{2}{*}{ Behavioral study } & \multirow{2}{*}{$\begin{array}{l}\text { Lower concentrations increased } \\
\text { motility, whereas the highest one } \\
\text { decreased the activity of both species. } \\
D \text {. rerio was less sensitive. Despite } D \text {. } \\
\text { rerio remained diurnally active, the } \\
\text { swimming activity of } L \text {. delineatus was } \\
\text { altered, reversing diurnal and nocturnal } \\
\text { activity }\end{array}$} & \multirow[t]{2}{*}{$\begin{array}{l}\text { Baganz et al } \\
(2004)\end{array}$} \\
\hline & $\begin{array}{l}\text { Sunbleak } \\
\text { (Leucaspius } \\
\text { delineatus) }\end{array}$ & & & & \\
\hline Pure MC-RR & $\begin{array}{l}\text { Peppered catfish } \\
\text { (Corydoras paleatus) }\end{array}$ & $\begin{array}{l}0.5,2,5 \text { or } 10 \mu \mathrm{g} / \mathrm{L} \text { for } 24 \\
\text { hours, by oral and } \\
\text { transdermal route }\end{array}$ & $\begin{array}{l}\text { Oxidative stress } \\
\text { parameters (GR, } \\
\text { POD, GPx, CAT } \\
\text { and LPO) and } \\
\text { detoxification } \\
\text { system (GST } \\
\text { activity) }\end{array}$ & $\begin{array}{l}\text { Increased LPO levels in brain of } \\
\text { exposed fish, and a general activation } \\
\text { of the antioxidant enzymatic system }\end{array}$ & $\begin{array}{l}\text { Cazenave et } \\
\text { al. (2006) }\end{array}$ \\
\hline Pure MC-RR & $\begin{array}{l}\text { Onesided livebearer } \\
\text { (Jenynsia } \\
\text { multidentata) }\end{array}$ & $\begin{array}{l}0.01,0.1 \text { or } 1 \mu \mathrm{g} / \mathrm{g} \text { for } 24 \\
\text { hours, by oral route }\end{array}$ & $\begin{array}{l}\text { Swimming activity } \\
\text { and detoxification } \\
\text { system (GST } \\
\text { activity) }\end{array}$ & $\begin{array}{l}\text { Low doses increased swimming } \\
\text { activity, while the highest dose headed } \\
\text { to small reduction after } 20 \text { hours }\end{array}$ & $\begin{array}{l}\text { Cazenave et } \\
\text { al. (2008) }\end{array}$ \\
\hline Pure MC-LR & $\begin{array}{l}\text { Zebrafish } \\
\text { (Danio rerio) }\end{array}$ & $\begin{array}{l}2 \text { or } 20 \mu \mathrm{g} / \mathrm{L} \text { for } 30 \text { days, by } \\
\text { oral and transdermal route }\end{array}$ & Protein expression & $\begin{array}{l}\text { Oxidative stress, dysfunction of } \\
\text { cytoskeleton assembly and } \\
\text { macromolecule metabolism, and } \\
\text { interference with signal transduction } \\
\text { and other functions in brain. The PP } \\
\text { activity rose with MC-LR concentration }\end{array}$ & $\begin{array}{l}\text { Wang et al. } \\
(2010)\end{array}$ \\
\hline Pure MC-LR & Zebrafish & $0.2,0.5,2$ and $5 \mathrm{mg} / \mathrm{L}$ at 96 & Protein and gene & Upregulation of CKs and DRP2 & Li et al. \\
\hline
\end{tabular}




\begin{tabular}{|c|c|c|c|c|c|}
\hline & (Danio rerio) & $\begin{array}{l}\text { hpf, by oral and transdermal } \\
\text { route }\end{array}$ & expression & & $(2011 b)$ \\
\hline $\begin{array}{l}\text { M. aeruginosa containing MC- } \\
\text { LR }\end{array}$ & $\begin{array}{l}\text { Rainbow trout } \\
\text { (Oncorhynchus } \\
\text { mykiss) }\end{array}$ & $\begin{array}{l}0.75,1.8 \text { and } 5 \mu \mathrm{g} / \mathrm{L} \text { for } 96 \\
\text { hours, by oral and } \\
\text { transdermal route }\end{array}$ & $\begin{array}{l}\text { Oxidative stress } \\
\text { parameters (GST } \\
\text { activity, LPO } \\
\text { levels), PBP and } \\
\text { AChE activity } \\
\end{array}$ & $\begin{array}{l}\text { Neither GSH activity nor LPO altered. } \\
\text { Lower levels of PBP and AChE }\end{array}$ & $\begin{array}{l}\text { Gélinas et al } \\
\text { (2012) }\end{array}$ \\
\hline $\begin{array}{l}\text { M. aeruginosa containing MC- } \\
\text { LR }\end{array}$ & $\begin{array}{l}\text { Zebrafish } \\
\text { (Danio rerio) }\end{array}$ & $\begin{array}{l}50 \text { or } 100 \mu \mathrm{g} / \mathrm{L} \text { for } 24 \text { hours, } \\
\text { by branchial and oral route }\end{array}$ & $\begin{array}{l}\text { AChE activity and } \\
\text { protein and gene } \\
\text { expression of } \\
\text { whole brain }\end{array}$ & $\begin{array}{l}\text { Enhancement of the AChE activity } \\
\text { depending on the exposure route }\end{array}$ & $\begin{array}{l}\text { Kist et al. } \\
(2012)\end{array}$ \\
\hline Pure MC-LR and MC-RR & $\begin{array}{l}\text { Zebrafish } \\
\text { (Danio rerio) }\end{array}$ & $\begin{array}{l}0.1,0.5,1,5 \text { or } 10 \mu \mathrm{g} / \mathrm{L} \text { for } \\
4,7 \text { and } 15 \text { days, by oral and } \\
\text { transdermal route }\end{array}$ & $\begin{array}{l}\text { Antioxidant } \\
\text { enzymatic } \\
\text { activities (GST, } \\
\text { GPx, GR and } \\
\text { SOD) } \\
\end{array}$ & $\begin{array}{l}\text { A bell shaped curve of response for } \\
\text { most of the parameters }\end{array}$ & $\begin{array}{l}\text { Pavagadhi et } \\
\text { al. (2012) }\end{array}$ \\
\hline Crude algae containing MC-RR & $\begin{array}{l}\text { Goldfish } \\
\text { (Carassius auratus) }\end{array}$ & $\begin{array}{l}0,50 \text { or } 200 \mu \mathrm{g} / \mathrm{kg} \text { b.w., } \\
\text { tested at } 6,12,24 \text { and } 48 \\
\text { hours, by intraperitoneal } \\
\text { injection }\end{array}$ & $\begin{array}{l}\text { Glucose levels and } \\
\text { antioxidant } \\
\text { enzymatic } \\
\text { activities (TAOC, } \\
\text { SOD, CAT and } \\
\text { GPx), } \\
\text { histopathological } \\
\text { study and protein } \\
\text { and gene } \\
\text { expression of } \\
\text { globin proteins }\end{array}$ & $\begin{array}{l}\text { The injection before hypoxia and } \\
\text { reoxygenation reduced antioxidant } \\
\text { capacity in most organs. Myoglobin and } \\
\text { neuroglobin mRNAs were induced in } \\
\text { the brain }\end{array}$ & $\begin{array}{l}\text { Okogwu et } \\
\text { al. (2014) }\end{array}$ \\
\hline $\begin{array}{l}\text { Planktothrix agardhii containing } \\
\text { MC-YR and MC-LR } \\
\text { M. aeruginosa containing MC- } \\
\text { LR }\end{array}$ & $\begin{array}{l}\text { Zebrafish } \\
\text { (Danio rerio) }\end{array}$ & $\begin{array}{l}0.3,1,3 \text { or } 10 \mathrm{~g} \text { d.w./L for } \\
96 \text { hours, by transdermal and } \\
\text { oral route }\end{array}$ & Behavioral study & $\begin{array}{l}\text { Slight increase of movement in } \\
\text { zebrafish embryos }\end{array}$ & $\begin{array}{l}\text { Jonas et al. } \\
(2015)\end{array}$ \\
\hline Pure MC-LR & $\begin{array}{l}\text { Zebrafish } \\
\text { (Danio rerio) }\end{array}$ & $\begin{array}{l}0.8,1.6 \text { or } 3.2 \mu \mathrm{g} / \mathrm{L} \text { for } 120 \\
\text { hpf, by transdermal and oral } \\
\text { route }\end{array}$ & $\begin{array}{l}\text { Developmental } \\
\text { toxicity and } \\
\text { locomotor study, } \\
\text { ACh and DA } \\
\text { levels, protein and }\end{array}$ & $\begin{array}{l}\text { Hypoactivity of larvae and alteration of } \\
\text { the cholinergic system }\end{array}$ & $\begin{array}{l}\text { Wu et al. } \\
(2016)\end{array}$ \\
\hline
\end{tabular}




\begin{tabular}{|c|c|c|c|c|c|}
\hline & & & $\begin{array}{l}\text { gene expression } \\
\text { related to } \\
\text { development, } \\
\text { AChE activity }\end{array}$ & & \\
\hline Pure MC-LR & $\begin{array}{l}\text { Zebrafish } \\
\text { (Danio rerio) }\end{array}$ & $\begin{array}{l}0.3,3 \text { or } 30 \mu \mathrm{g} / \mathrm{L} \text { for } 90 \\
\text { days, by transdermal and } \\
\text { oral route }\end{array}$ & $\begin{array}{l}\text { Histopathological } \\
\text { study and protein } \\
\text { and gene } \\
\text { expression of } \\
\text { GABA and } \\
\text { glutamate }\end{array}$ & $\begin{array}{l}\text { Edematous and collapsed myelinated } \\
\text { nerve fibers, distention of endoplasmic } \\
\text { reticulum and swelling mitochondria in } \\
\text { brain }\end{array}$ & $\begin{array}{l}\text { Yan et al. } \\
(2017)\end{array}$ \\
\hline Pure MC-LR & $\begin{array}{l}\text { Zebrafish } \\
\text { (Danio rerio) }\end{array}$ & $\begin{array}{l}1,5 \text { or } 25 \mu \mathrm{g} / \mathrm{L} \text { for } 60 \text { days, } \\
\text { by transdermal and oral } \\
\text { route }\end{array}$ & $\begin{array}{l}\text { Behavioral study, } \\
\text { protein and gene } \\
\text { expression, levels } \\
\text { of MC-LR, DA, } \\
\text { GABA, serotonin, } \\
\text { ACh and DOPAC, } \\
\text { and AChE activity }\end{array}$ & $\begin{array}{l}\text { Parental exposure resulted in MC-LR } \\
\text { accumulation and developmental } \\
\text { neurotoxicity in offsprings }\end{array}$ & $\begin{array}{l}\text { Wu et al. } \\
(2017)\end{array}$ \\
\hline $\begin{array}{l}\text { M. aeruginosa containing MC- } \\
\text { LR }\end{array}$ & $\begin{array}{l}\text { Zebrafish } \\
\text { (Danio rerio) }\end{array}$ & $\begin{array}{l}0.02,0.04 \text { or } 0.08 \text { OD } \\
\text { values, for } 4 \text { days, by } \\
\text { transdermal and oral route }\end{array}$ & $\begin{array}{l}\text { Locomotor } \\
\text { behavioral study, } \\
\text { gene expression, } \\
\text { AChE and DA } \\
\text { levels }\end{array}$ & $\begin{array}{l}\text { Affectation of both cholinergic and } \\
\text { dopaminergic systems changes in the } \\
\text { gene transcription of the nervous } \\
\text { system, and a decrease of the locomotor } \\
\text { activity in larval zebrafish }\end{array}$ & $\begin{array}{l}\text { Qian et al. } \\
(2018)\end{array}$ \\
\hline
\end{tabular}

Abbreviations: ACh: acetylcholine; AChE: acetylcholinesterase; b.w.: body weight; CAT: catalase; CKs: creatine kinases; DA: dopamine; DOPAC: dihydroxyphenylacetic acid; DRP2: dihydropyrimidinase-like 2; d.w.: dry weight; GABA: gamma-aminobutyric acid; GPx: glutathione peroxidase; GR: glutathione reductase; GST: glutathione-Stransferase; hpf: hours post-fertilization; LPO: lipid peroxidation; OD: optical density; PBP: protein-bound phosphate; POD: guaiacol peroxidase activity; SOD: superoxide dismutase; TAOC: total antioxidant capacity. 
Table 5.

\begin{tabular}{|c|c|c|c|c|c|}
\hline CYN/Cyanobacteria & $\begin{array}{c}\text { Experimental } \\
\text { model }\end{array}$ & Experimental conditions & Assays performed & Relevant Results & References \\
\hline \multicolumn{6}{|c|}{ In vitro } \\
\hline $\begin{array}{l}\text { Crude extracts of } \\
\text { C. raciborskii }\end{array}$ & $\begin{array}{l}\text { Neurons of Helix } \\
\text { pomatia }\end{array}$ & $\begin{array}{l}\text { Extracts of both the bloom sample } \\
\text { and the laboratory isolate of the } \\
\text { bloom were diluted in } \\
\text { physiological Helix saline and } \\
\text { applied by perfusion at a constant } \\
\text { flow rate }\end{array}$ & $\begin{array}{l}\text { Electrophysiological } \\
\text { experiments }\end{array}$ & $\begin{array}{l}\text { No cholinergic alteration was } \\
\text { observed with the CYN-producing } \\
\text { strain }\end{array}$ & $\begin{array}{l}\text { Vehovszky et } \\
\text { al. }(2013)\end{array}$ \\
\hline \multirow[t]{2}{*}{ Pure CYN } & $\begin{array}{l}\text { N2a murine } \\
\text { neuroblastoma } \\
\text { derived cells }\end{array}$ & \multirow[t]{2}{*}{$\begin{array}{l}0.001,0.1 \text { and } 10 \mu \mathrm{M} \text { for } 24,48 \\
\text { and } 72 \text { hours }\end{array}$} & \multirow[t]{2}{*}{$\begin{array}{l}\text { MTT assay } \\
\text { Apoptotic cell death } \\
\text { TNF- } \alpha \text { measurement }\end{array}$} & $\begin{array}{l}\text { Concentration and time-dependent } \\
\text { decrease of cell viability after all time } \\
\text { exposures to both } 0.1 \text { and } 10 \mu \mathrm{M} \text {. } \\
\text { Significant rise in proapoptotic } \\
\text { caspases after exposure to } 10 \mu \mathrm{M}\end{array}$ & \multirow[t]{2}{*}{$\begin{array}{l}\text { Takser et al. } \\
(2016)\end{array}$} \\
\hline & $\begin{array}{l}\text { BV-2 microglia } \\
\text { murine cells }\end{array}$ & & & $\begin{array}{l}\text { Concentration-dependent decrease of } \\
\text { cell viability after all exposure times } \\
\text { to both } 0.1 \text { and } 10 \mu \mathrm{M} \text {. Significant } \\
\text { rise in proapoptotic caspases after } \\
\text { exposure to } 10 \mu \mathrm{M}\end{array}$ & \\
\hline \multicolumn{6}{|c|}{ In vivo } \\
\hline $\begin{array}{l}\text { Whole cell extracts of } \\
\text { C. raciborskii and live } \\
\text { cultures of } C \text {. raciborskii }\end{array}$ & $\begin{array}{l}\text { Bufo marinus } \\
\text { tadpoles }\end{array}$ & $\begin{array}{l}0-200 \text { and } 0-107 \mu \mathrm{g} / \mathrm{L}, \\
\text { respectively, for } 7 \text { days, by } \\
\text { transdermal route }\end{array}$ & Histopathological study & $\begin{array}{l}\text { No mortality observed. Several } \\
\text { histopathological changes in the } \\
\text { encephalon }\end{array}$ & $\begin{array}{l}\text { Kinnear et al. } \\
(2007)\end{array}$ \\
\hline $\begin{array}{l}\text { Whole cell extracts of } \\
\text { C. raciborskii }\end{array}$ & \multirow[t]{2}{*}{$\begin{array}{l}\text { Bufo marinus } \\
\text { tadpoles }\end{array}$} & $\begin{array}{l}0-400 \mu \mathrm{g} / \mathrm{L} \text { for } 7 \text { days, by } \\
\text { transdermal route }\end{array}$ & \multirow[t]{2}{*}{$\begin{array}{l}\text { Behavioral studies } \\
\text { Toxin analysis }\end{array}$} & $\begin{array}{l}\text { Decrease in behavior scores } \\
\text { Neither mortality nor growth rates } \\
\text { were affected }\end{array}$ & \multirow[t]{2}{*}{$\begin{array}{l}\text { White et al. } \\
(2007)\end{array}$} \\
\hline $\begin{array}{l}\text { Live cultures of } \\
\text { C. raciborskii }\end{array}$ & & $\begin{array}{l}0-232 \mu \mathrm{g} / \mathrm{L} \text { for } 7 \text { days, by } \\
\text { transdermal route }\end{array}$ & & $\begin{array}{l}\text { Decrease in behavior scores } \\
\text { Time-dependent increase in mortality } \\
\text { Negative growth rates }\end{array}$ & \\
\hline $\begin{array}{l}\text { A. ovalisporum culture } \\
\text { containing CYN }\end{array}$ & $\begin{array}{l}\text { Tilapia fish } \\
\text { (Oreochromis } \\
\text { nicotilus) }\end{array}$ & $\begin{array}{l}10 \mu \mathrm{g} / \mathrm{L} \text { for } 14 \text { days, by } \\
\text { transdermal and oral route }\end{array}$ & $\begin{array}{l}\text { AChE activity, LPO, } \\
\text { histopathological study } \\
\text { and ELISA }\end{array}$ & $\begin{array}{l}\text { Inhibition of the AChE activity } \\
\text { Rise in LPO levels } \\
\text { Necrosis, hyperemia, haemorrhagia } \\
\text { and edema } \\
\text { CYN detection in all brain samples }\end{array}$ & $\begin{array}{l}\text { Guzmán- } \\
\text { Guillén et al. } \\
(2015)\end{array}$ \\
\hline
\end{tabular}




\begin{tabular}{|c|c|c|c|c|c|}
\hline $\begin{array}{l}\text { Purified CYN (CYNp) and } \\
\text { extract of C. raciborskii } \\
\text { containing CYN (CYNex) }\end{array}$ & $\begin{array}{l}\text { Trahira } \\
\text { (Hoplias } \\
\text { malabaricus) }\end{array}$ & $\begin{array}{l}\text { Single dose of } 50 \mu \mathrm{g} / \mathrm{kg} \text { b.w. for } 7 \\
\text { and } 14 \text { days by intraperitoneal } \\
\text { injection }\end{array}$ & $\begin{array}{l}\text { AChE activity, GST } \\
\text { activity, LPO and ELISA }\end{array}$ & $\begin{array}{l}\text { Increase of AChE activity after } 7 \text { days } \\
\text { of exposure to CYNex, decreasing } \\
\text { after } 14 \text { days. } \\
\text { Decrease of GST after } 7 \text { days of } \\
\text { exposure to CYNex and increase after } \\
7 \text { days of exposure to CYNex and } \\
\text { after } 14 \text { days of exposure to CYNp } \\
\text { and CYNex. } \\
\text { Rise in LPO levels after } 7 \text { and } 14 \text { days } \\
\text { of exposure to CYNp and CYNex. } \\
\text { Detection of CYN in brain }\end{array}$ & $\begin{array}{l}\text { da Silva et al } \\
(2018)\end{array}$ \\
\hline
\end{tabular}

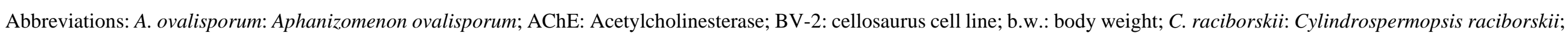

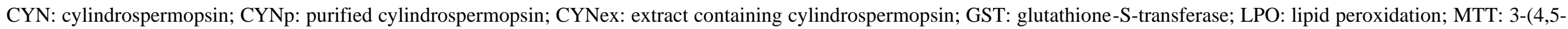
dimethylthiazol-2-yl)-2,5-diphenyltetrazolium bromide; N2a: fast-growing mouse neuroblastoma cells. 
Table 4.

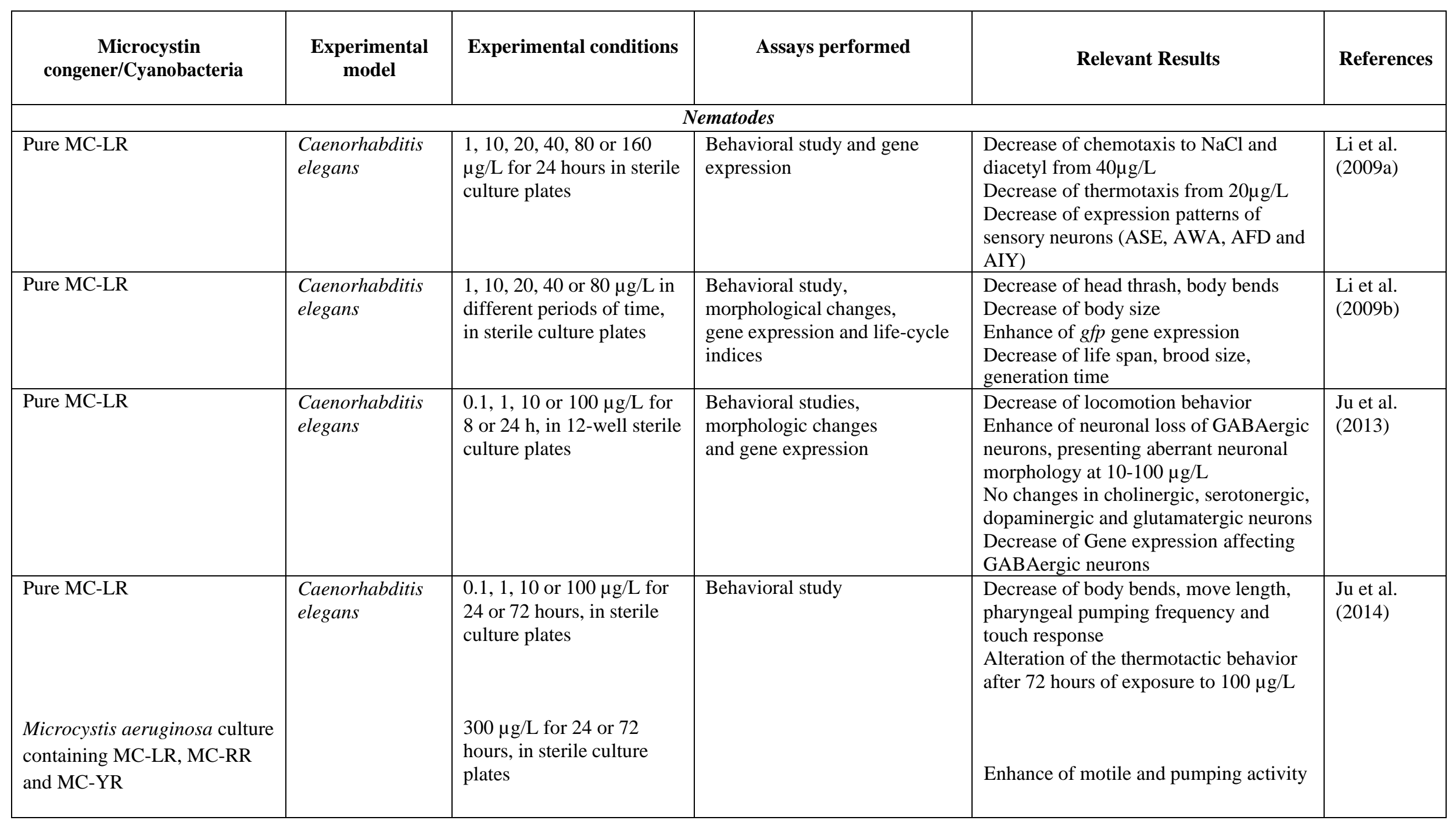




\begin{tabular}{|c|c|c|c|c|c|}
\hline $\begin{array}{l}\text { Pure MC-LR } \\
\text { Pure MC-LF }\end{array}$ & $\begin{array}{l}\text { Caenorhabditis } \\
\text { elegans }\end{array}$ & $\begin{array}{l}1,10,40,80,160,320, \\
500, \text { or } 1000 \mu \mathrm{g} / \mathrm{L} \text { for } 24 \\
\text { hours, } \\
\text { in sterile culture plates } \\
1,10,100,160 \text { or } 320 \\
\mu \mathrm{g} / \mathrm{L} \text { for } 24 \text { hours, in } \\
\text { sterile culture plates }\end{array}$ & Function of sensory neurons & $\begin{array}{l}\text { Affectation of AWA sensory neurons, } \\
\text { but not of AWC sensory neurons: MC- } \\
\text { LF >MC-LR }\end{array}$ & $\begin{array}{l}\text { Moore et al. } \\
(2014)\end{array}$ \\
\hline Pure MC-LR & $\begin{array}{l}\text { Caenorhabditis } \\
\text { elegans }\end{array}$ & $\begin{array}{l}1,50 \text { or } 100 \mu \mathrm{g} / \mathrm{L} \text { in } \\
\text { different periods for life } \\
\text { cycle, in sterile culture } \\
\text { plates }\end{array}$ & $\begin{array}{l}\text { Life-cycle indices and gene } \\
\text { expression }\end{array}$ & $\begin{array}{l}\text { Decrease of lifespan, body length and } \\
\text { brood size after } 100 \mu \mathrm{g} / \mathrm{L} \text { of exposure } \\
\text { Alteration of genes expression after } 100 \\
\mu \mathrm{g} / \mathrm{L} \text { of exposure }\end{array}$ & $\begin{array}{l}\text { Saul et al. } \\
(2014)\end{array}$ \\
\hline \multicolumn{6}{|c|}{ Birds } \\
\hline $\begin{array}{l}\text { Cyanobacterial biomass } \\
\text { containing MC-LR, MC-RR, } \\
\text { MC-YR and MCs similar } \\
\text { compounds }\end{array}$ & $\begin{array}{l}\text { Japanese quail } \\
\text { (Coturnix } \\
\text { coturnix } \\
\text { japonica) }\end{array}$ & $\begin{array}{l}0.045,0.459,4.605 \text { or } \\
46.044 \mu \mathrm{g} / \text { day for } 10 \text { or } 30 \\
\text { days, by oral route }\end{array}$ & Oxidative stress parameters & $\begin{array}{l}\text { Alteration in brain, after acute exposure: } \\
\text { Decrease of GSH, Enhance of TBARS, } \\
\text { Enhance of EROD. After subchronic } \\
\text { exposure: Enhance of GSH, Enhance of } \\
\text { GPx Enhance of TBARS, Enhance of } \\
\text { EROD }\end{array}$ & $\begin{array}{l}\text { Pašková et } \\
\text { al. (2008) }\end{array}$ \\
\hline \multicolumn{6}{|c|}{ Mammals } \\
\hline $\begin{array}{l}\text { MC raw extracts containing } \\
\text { mainly [D-Leu }] \text { MC-LR }\end{array}$ & Rats & $\begin{array}{l}1 \mu \mathrm{L} \text { of extracts containing } \\
0.01 \text { or } 20 \mu \mathrm{g} / \mathrm{L} \\
\text { (equivalent to } 0.045 \times 10 \mathrm{E}- \\
6 \text { and } 9.1 \times 10 \mathrm{E}-5 \mu \mathrm{g} / \mathrm{kg} \text { ) by } \\
\text { intrahippocampal injection }\end{array}$ & $\begin{array}{l}\text { Behavioral study, oxidative } \\
\text { stress parameters and DNA } \\
\text { damage }\end{array}$ & $\begin{array}{l}\text { Enhance of latency of long-term } \\
\text { memory in rats exposed to } 20 \mu \mathrm{g} / \mathrm{L} \\
\text { Decrease of latency of memory retrieval } \\
\text { Enhance of working and reference } \\
\text { memory errors after } 8 \text { days of exposure } \\
\text { Enhance of GST activity in brain rats } \\
\text { exposed to } 0.01 \mu \mathrm{g} / \mathrm{L} \\
\text { Enhance of LPO content in brain rats } \\
\text { exposed to } 20 \mu \mathrm{g} / \mathrm{L} \\
\text { DNA damage in brain of both MCs } \\
\text { doses treated rats }\end{array}$ & $\begin{array}{l}\text { Maidana et } \\
\text { al. (2006) }\end{array}$ \\
\hline $\begin{array}{l}\text { Extracted and purified MC-LR } \\
\text { and MC-RR from blooms }\end{array}$ & Rats & $\begin{array}{l}80 \mu \mathrm{g} \text { MC-LReq/kg b.w. } \\
\text { injected i.v. } \\
\text { The analysis was } \\
\text { performed } 1,2,4,6,12 \\
\text { and } 24 \text { hours post-injection }\end{array}$ & $\begin{array}{l}\text { Determination of MCs content } \\
\text { in different tissues by LC-MS }\end{array}$ & $\begin{array}{l}\text { MCs contents in brain }(0.2 \%) \text { : } \\
2>24>1>12>6 \approx 4 \text { hours post- } \\
\text { injection } \\
\text { kidney }>\text { lung }>\text { stomach }>\text { liver }>\text { small }\end{array}$ & $\begin{array}{l}\text { Wang et al. } \\
(2008)\end{array}$ \\
\hline
\end{tabular}




\begin{tabular}{|c|c|c|c|c|c|}
\hline & & & & $\begin{array}{l}\text { intestine }>\text { gonad }>\text { spleen }>\text { muscle }> \\
\text { heart }>\text { brain }\end{array}$ & \\
\hline Pure MC-LR & Rats & $\begin{array}{l}1 \mu \mathrm{L} \text { containing } 1 \text { or } 10 \\
\mu \mathrm{g} / \mathrm{L} \text { MC-LR (equivalent } \\
\text { to } 5 \times 10 \mathrm{E}-6 \text { or } 5 \times 10 \mathrm{E}-5 \\
\mu \mathrm{g} / \mathrm{kg} \text { ), } \\
\text { bilaterally injected into } \\
\text { hippocampal. } \\
\text { Parameters were measured } \\
15 \text { days post-injection }\end{array}$ & $\begin{array}{l}\text { Behavioral study, } \\
\text { histopathological study and } \\
\text { oxidative stress parameters }\end{array}$ & $\begin{array}{l}\text { Enhance of latencies to find the platform } \\
\text { Decrease of swimming distance in the } \\
\text { target zone } \\
\text { Swimming speed did not change } \\
\text { Decrease of total hipoccampal neurons } \\
\text { Highest MC-LR dose: Enhance of LPO, } \\
\text { Enhance of CAT, Enhance of GPx, } \\
\text { Enhance of SOD } \\
\text { Lowest MC-LR dose: Enhance of LPO, } \\
\text { Enhance of CAT }\end{array}$ & $\begin{array}{l}\text { Li et al. } \\
(2012 a)\end{array}$ \\
\hline Pure MC-LR & Rats & $\begin{array}{l}1 \text { or } 10 \mu \mathrm{g} / \mathrm{kg} \text { day i.p. } \\
\text { injected for } 50 \text { days }\end{array}$ & $\begin{array}{l}\text { Behavioral study, } \\
\text { histopathological study, protein } \\
\text { expression, } \\
\text { MC-LR content analysis }\end{array}$ & $\begin{array}{l}\text { Enhance of latencies to find the platform } \\
\text { Decrease of swimming distance in the } \\
\text { target zone } \\
\text { Enhance of degeneration and apoptosis } \\
\text { of hippocampal cells } \\
\text { Hyperphosphorylation of tau } \\
41.6 \pm 8.45 \mathrm{ng} / \mathrm{g} \text { d.w. of MC-LR was } \\
\text { detected in brain of rats exposed to } 10 \\
\mu \mathrm{g} / \mathrm{kg} \text { day }\end{array}$ & $\begin{array}{l}\text { Li et al. } \\
(2012 b)\end{array}$ \\
\hline Pure MC-LR & Rats & $\begin{array}{l}10 \mu \mathrm{L} \text { containing } 5 \text { or } 25 \\
\mu \mathrm{g} / \mathrm{L} \text { (equivalent to } \\
2.5 \times 10 \mathrm{E}-4 \text { or } 1.25 \times 10 \mathrm{E}-3 \\
\mu \mathrm{g} / \mathrm{kg} \text { ), by i.c. } \mathrm{v} \text {. injection } \\
\text { MC-LR }+\mathrm{LiCl} \text { and } \\
\text { SB216763 inhibitors of } \\
\text { GSK-3 } \beta\end{array}$ & Electrophysiologycal studies & $\begin{array}{l}\text { Enhance of PPs activity } \\
\text { Decrease of phosphorilated GSK-3 } \\
\text { Decrease of LTP } \\
\text { Inhibitors avoid effects produced by } \\
\text { MC-LR }\end{array}$ & $\begin{array}{l}\text { Wang et al. } \\
\text { (2013) }\end{array}$ \\
\hline Pure MC-LR & Rats & $\begin{array}{l}0.2,1 \text { or } 5 \mu \mathrm{g} / \mathrm{kg} \text { every } 2 \\
\text { days for } 8 \text { weeks, by } \\
\text { intragastric route }\end{array}$ & $\begin{array}{l}\text { Behavioral study, } \\
\text { histopathological study and } \\
\text { immunohistochemistry staining }\end{array}$ & $\begin{array}{l}\text { Enhance of escape latencies in } 5 \mu \mathrm{g} / \mathrm{kg} \\
\text { MC-LR-treated rats } \\
\text { Decrease of frequencies entering the } \\
\text { enlarged platform in } 1 \text { and } 5 \mu \mathrm{g} / \mathrm{kg} \mathrm{MC} \text { - } \\
\text { LR-treated rats } \\
\text { No significant differences in the number } \\
\text { of damaged neurons }\end{array}$ & $\begin{array}{l}\text { Li et al. } \\
(2014)\end{array}$ \\
\hline
\end{tabular}




\begin{tabular}{|c|c|c|c|c|c|}
\hline & & & & $\begin{array}{l}\text { Enhance of astrocyte density and NO } \\
\text { concentration in hippocampus exposed } \\
\text { to } 5.0 \mu \mathrm{g} / \mathrm{kg}\end{array}$ & \\
\hline Pure MC-LR & Rats & $\begin{array}{l}1,5 \text { or } 20 \mu \mathrm{g} / \mathrm{kg} \text { every } 2 \\
\text { days for } 8 \text { weeks, by } \\
\text { intragastric route. Later the } \\
\text { rats became pregnant of a } \\
\text { non-exposed male }\end{array}$ & $\begin{array}{l}\text { Maternal toxicity and } \\
\text { reproductive outcome, simple } \\
\text { motor and locomotor activities, } \\
\text { behavioral study and oxidative } \\
\text { stress parameters }\end{array}$ & $\begin{array}{l}\text { Decrease of mean body weight gain in } \\
\text { maternal rats. } \\
\text { Decrease of number of pregnant rats } \\
\text { Alteration of behavior and } \\
\text { neurodevelopment in rat offsprings } \\
\text { Enhance of MDA and SOD in } \\
\text { hippocampus of offsprings }\end{array}$ & $\begin{array}{l}\text { Li et al. } \\
(2015 b)\end{array}$ \\
\hline $\begin{array}{l}\text { Extracted and purified MC-LR } \\
\text { from blooms }\end{array}$ & $\begin{array}{l}\text { Pregnant rats and } \\
\text { pups }\end{array}$ & $\begin{array}{l}10 \mu \mathrm{g} / \mathrm{kg} \text { daily from day } 8 \\
\text { to postnatal day } 15\end{array}$ & $\begin{array}{l}\text { Oxidative stress parameters, } \\
\text { determination of MC-LR, } \\
\text { histopathological study and } \\
\text { protein expression }\end{array}$ & $\begin{array}{l}\text { Enhance of MDA, Decrease of GSH } \\
\text { andAChE activity } \\
\text { No significant PPs changes } \\
3.75 \pm 0.94 \mathrm{ng} / \mathrm{g} \mathrm{d} . \mathrm{w} \text {. were detected in } \\
\text { brain of pup rats } \\
\text { Morphological changes } \\
\text { Alteration of proteins involved in } \\
\text { neuronal processes in pup rats }\end{array}$ & $\begin{array}{l}\text { Zhao et al. } \\
(2015)\end{array}$ \\
\hline $\begin{array}{l}\text { Extracted and purified MC-LR } \\
\text { from blooms }\end{array}$ & Mice & $\begin{array}{l}1 \mu \mathrm{L} \text { containing } 1-20 \\
\mathrm{ng} / \mu \mathrm{L} \text {, by i.c.v. route. All } \\
\text { parameters measured } 3 \\
\text { hours, } 1 \text { day, } 3 \text { day and } 7 \\
\text { day after exposure }\end{array}$ & $\begin{array}{l}\text { Behavioral study, } \\
\text { histopathological study and } \\
\text { oxidative stress parameters }\end{array}$ & $\begin{array}{l}\text { Decrease of memory impairment } \\
\text { Morphological changes in hippocampal } \\
\text { neurons from } 10 \mathrm{ng} / \mu \mathrm{L} \\
\text { Enhance of protein oxidation, LPO, } \\
\text { ROS, SOD, GPx and Nrf2 } \\
\text { Decrease of GSH/GSSG }\end{array}$ & $\begin{array}{l}\text { Shin et al. } \\
(2018)\end{array}$ \\
\hline Pure MC-LR & Mice & $\begin{array}{l}1,5,10,20 \text { or } 40 \mu \mathrm{g} / \mathrm{L} 12 \\
\text { weeks, by oral route }\end{array}$ & $\begin{array}{l}\text { Histopathological study and } \\
\text { protein expression }\end{array}$ & $\begin{array}{l}\text { Pathological changes in hippocampus } \\
\text { and cortical cells in a dose-dependent } \\
\text { way. Differences between hippocampus } \\
\text { and cerebral cortex in the affectation of } \\
\text { mRNA and proteins expression: ATP6, } \\
\text { COX3, CYTB, POLG, mtSSB and } \\
\text { TFAM }\end{array}$ & $\begin{array}{l}\text { Wang et al. } \\
(2018)\end{array}$ \\
\hline Pure MC-LR & Rats & $\begin{array}{l}3 \mu \mathrm{L} \text { of } 0.1 \mu \mathrm{g} \mathrm{MC}-\mathrm{LR} / \mu \mathrm{L} \\
\text { (equivalent to } 1.5 \mu \mathrm{g} / \mathrm{kg} \text { ) } \\
\text { via hippocampal injection. } \\
\text { All parameters measured } \\
24 \text { hours, before and after }\end{array}$ & $\begin{array}{l}\text { Protein expression and } \\
\text { behavioral study }\end{array}$ & $\begin{array}{l}\text { Enhance of desmethylation of PP2Ac, } \\
\text { phosphorylation of GSK-3 } \beta \text { and tau, } \\
\text { spatial memory deficit. }\end{array}$ & $\begin{array}{l}\text { Zhang et al } \\
(2018)\end{array}$ \\
\hline
\end{tabular}




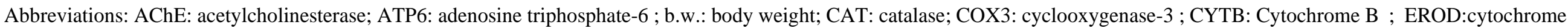

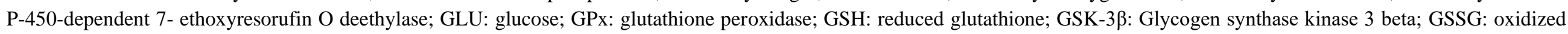

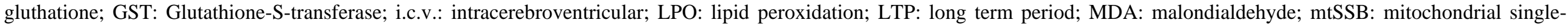

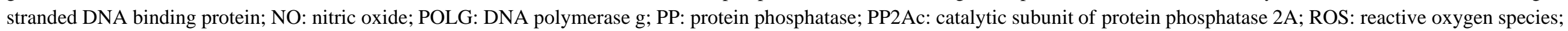
SOD: superoxide dismutase; TBARS: total thiobarbituric acid reactive species; TFAM: mitochondrial transcription factor A. 


\section{Table captions}

Table 1. Properties and environmental concentrations of some MCs congeners and CYN.

Table 2. In vitro neurotoxicity studies after exposure to MCs.

Table 3. In vivo neurotoxicity studies in several aquatic animal models exposed to MCs.

Table 4. In vivo neurotoxicity studies in different terrestrial models exposed to MCs.

Table 5. Neurotoxicity studies performed with CYN. 
Figure A.

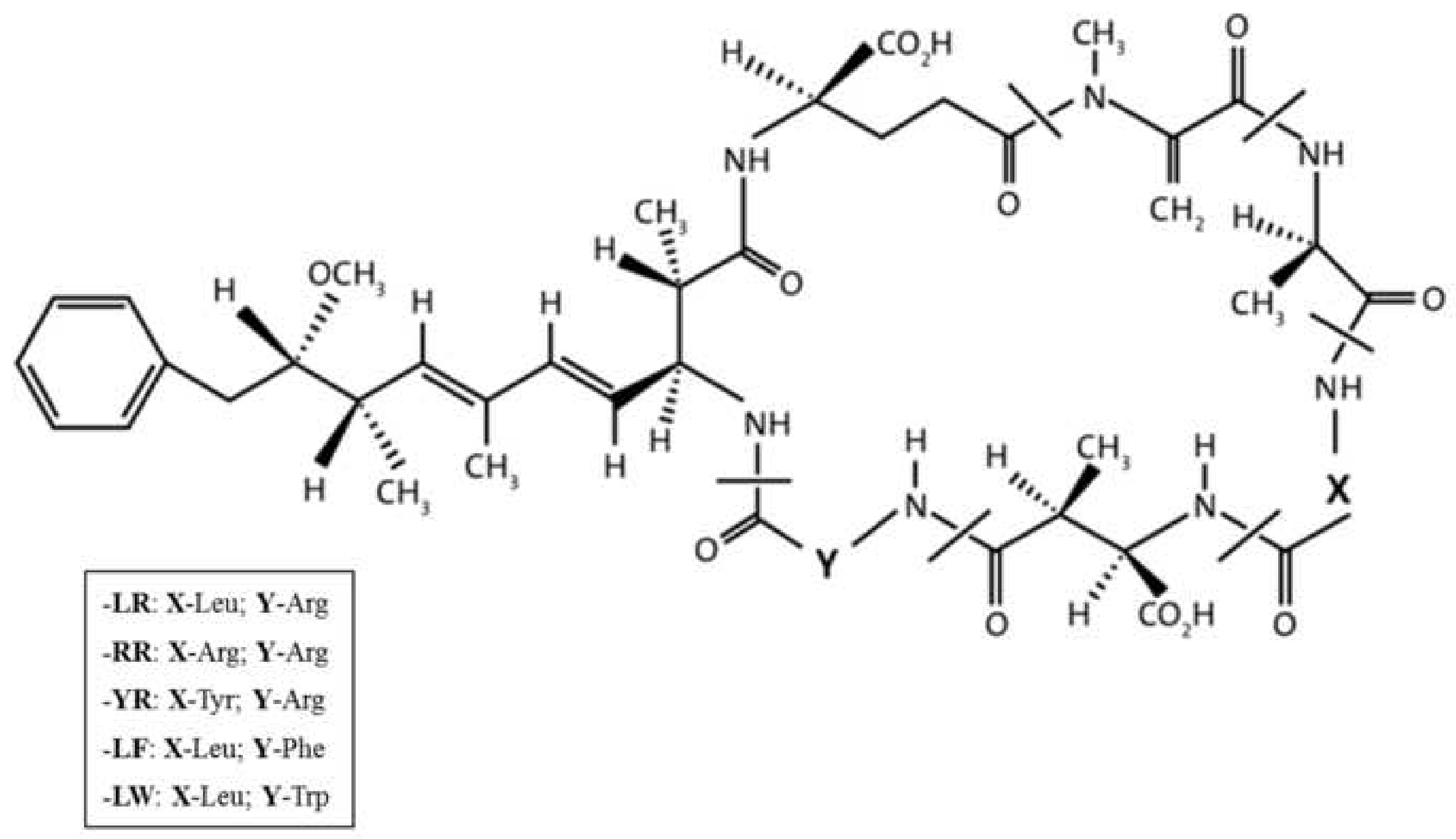


Figure B

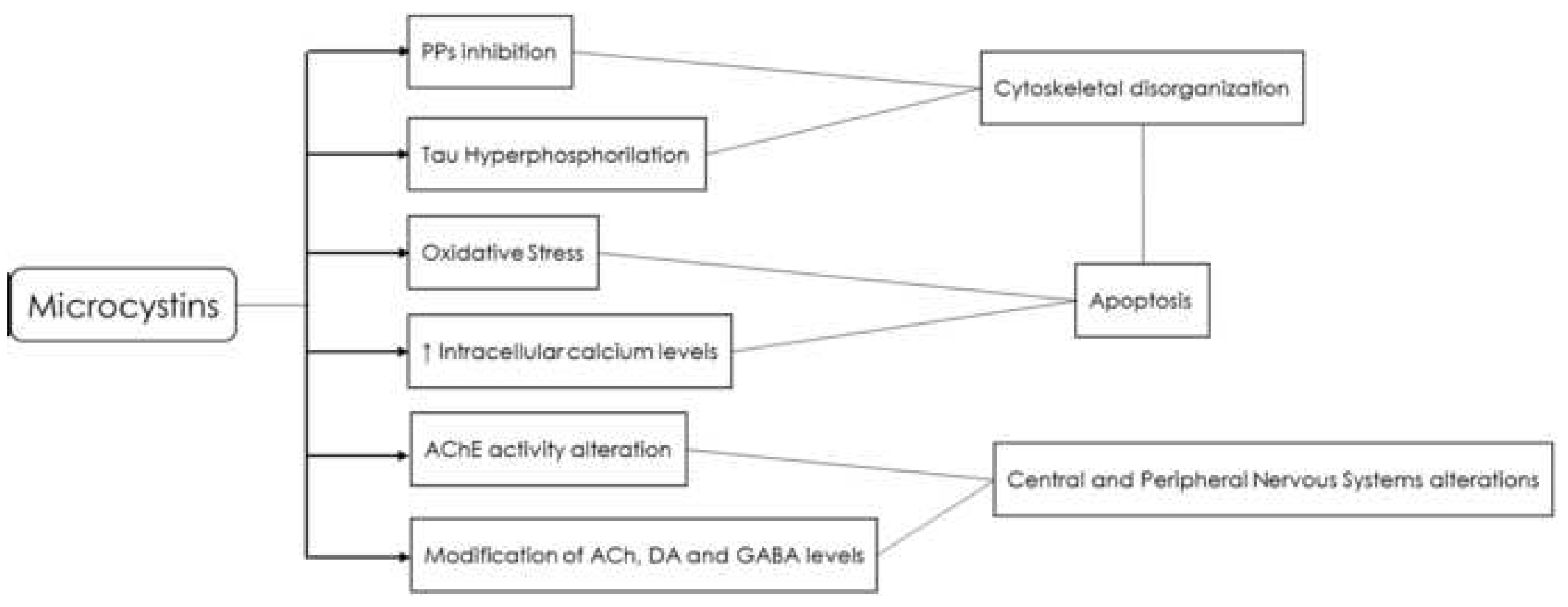


Figure C.

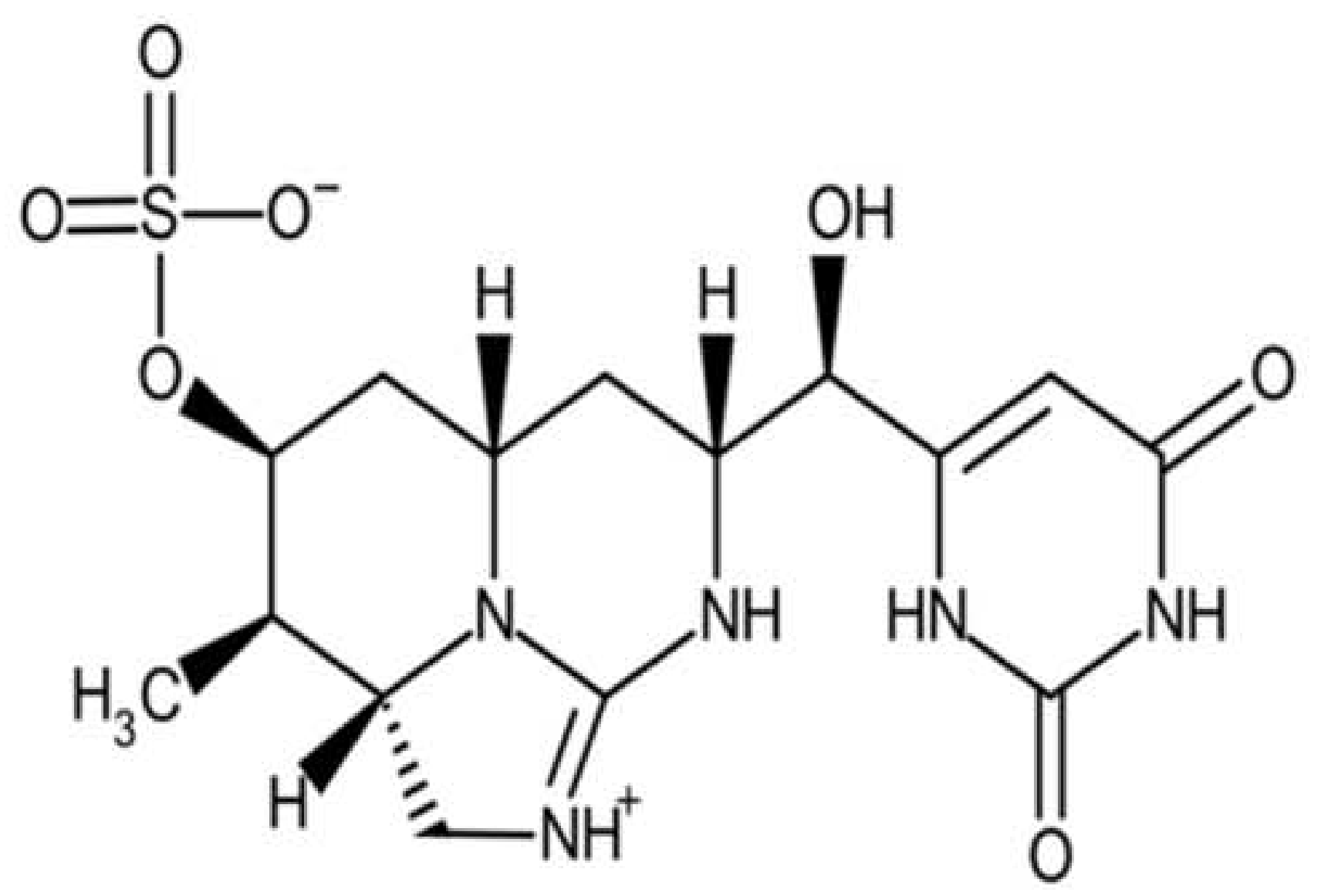


Figure D.

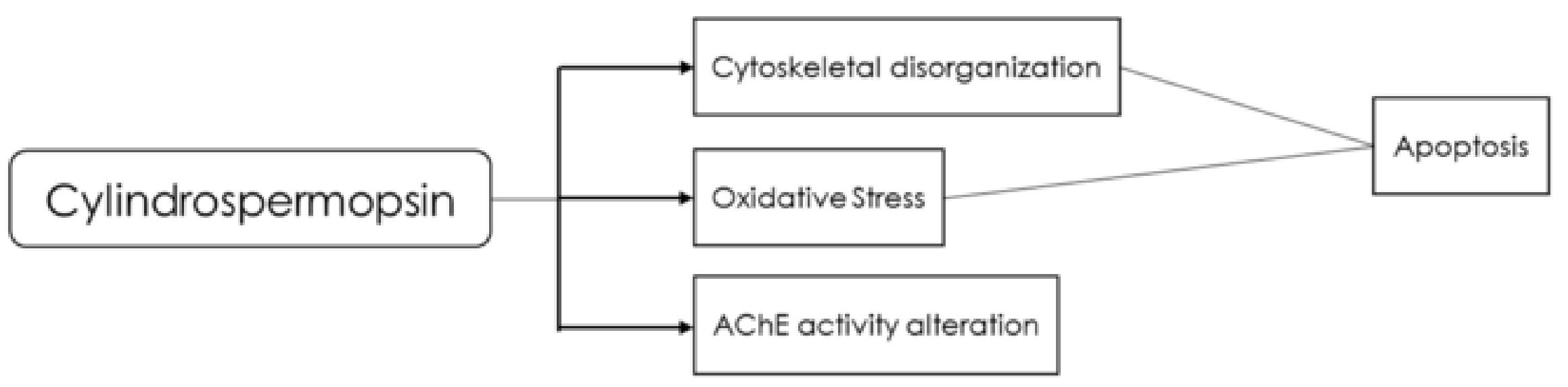


Figure captions

\section{Figure captions:}

Figure A. Structure of MCs.

Figure B. Main mechanisms of neurotoxic action of MCs.

Figure C. Structure of CYN.

Figure D. Main mechanisms of neurotoxic action of CYN. 